\title{
Argon-40/argon-39 age spectra of Apollo 17 highlands breccia samples by laser step heating and the age of the Serenitatis basin
}

\author{
G. Brent Dalrymple \\ College of Oceanic and Atmospheric Sciences, Oregon State University, Corvallis \\ Graham Ryder \\ Lunar and Planetary Institute, Houston, Texas
}

\begin{abstract}
We have obtained high-resolution (21-63 steps) ${ }^{40} \mathrm{Ar} /{ }^{39} \mathrm{Ar}$ age spectra using a continuous laser system on 19 submilligram samples of melt rocks and clasts from Apollo 17 samples collected from the pre-Imbrian highlands in the easternmost part of the Serenitatis basin. The samples include poikilitic melt rocks inferred to have been formed in the Serenitatis basin-forming impact, aphanitic melt rock whose compositions vary and whose provenance is uncertain, and granulite, gabbro, and melt clasts. Three of the poikilitic melts have similar age spectrum plateau ages $(72395,96,3893 \pm 16 \mathrm{Ma}\{2 \sigma\} ; 72535,7,3887 \pm 16 \mathrm{Ma} ; 76315,150,3900 \pm 16 \mathrm{Ma})$ with a weighted mean age of $3893 \pm 9 \mathrm{Ma}$, which we interpret as the best age for the Serenitatis basinforming impact. Published ${ }^{40} \mathrm{Ar} /{ }^{34} \mathrm{Ar}$ age spectrum ages of Apollo 17 poikilitic melts are consistent with our new age but are much less precise. Two poikilitic melts did not give plateaus and the maxima in their age spectra indicate ages of $\geq 3869 \mathrm{Ma}(72558,7)$ and $\geq 3743 \mathrm{Ma}(77135,178)$. Plateau ages of two poikilitic melts and two gabbro clasts from 73155 range from $3854 \pm 16 \mathrm{Ma}$ to $3937 \pm 16 \mathrm{Ma}$ and have probably been affected by the ubiquitous (older?) clasts and by postformation heating (impact) events. Plateau ages from two of the aphanitic melt "blobs" and two granulites in sample 72255 fall in the narrow range of $3850 \pm 16 \mathrm{Ma}$ to $3869 \pm 16 \mathrm{Ma}$ with a weighted mean of $3862 \pm 8 \mathrm{Ma}$. Two of the aphanitic melt blobs from 72255 have ages of $3883 \pm$ $16 \mathrm{Ma}$ and $\geq 3894 \mathrm{Ma}$, whereas a poikilitic melt clast (of different composition from the "Serenitatis" melts) has an age of $3835 \pm 16 \mathrm{Ma}$, which is the upper limit for the accretion of 72255. These data suggest that either the aphanitic melts vary in age, as is also suggested by their varying chemical compositions, or they formed in the 72255 accretionary event about 3.84-3.85 $\mathrm{Ga}$ and older relict material is responsible for the dispersion of ages. In any case the aphanitic melts do not appear to be Serenitatis products. Our age for the Serenitatis impact shows, on the basis of the isotopic age evidence alone, that Serenitatis is $>20-25 \mathrm{Ma}$ and probably $>55-60 \mathrm{Ma}$ older than Imbrium ( $\leq 3870 \mathrm{Ma}$ and probably $\leq 3836 \mathrm{Ma}$ [Dalrymple and Ryder, 1993]). Noritic granulite sample 78527 has a plateau age of $4146 \pm 17 \mathrm{Ma}$, representing a minimum age for cooling of this sample in the early lunar crust. So far there is no convincing evidence in the lunar melt rock record for basin-forming impacts significantly older than $3.9 \mathrm{Ga}$.
\end{abstract}

\section{Introduction}

In this paper we report results from a study whose primary purpose is (1) to determine precisely the formation ages of a variety of lunar impact melt rocks of well characterized compositions from precise and detailed ${ }^{41} \mathrm{Ar} /{ }^{39} \mathrm{Ar}$ age spectra, (2) to determine more precisely the ages of some of the major basin-forming impacts, and (3) to determine whether the Moon was subjected to a continuous heavy bombardment that ended abruptly about $3.9 \mathrm{Ga}$

Copyright 1996 by the American Geophysical Union

Paper number $96 \mathrm{JE} 02806$.

0148-0227/96/96JE-02806\$09.00 following a steady decline in impact rate, or whether the impact frequency following accretion was rather low and the heavy bombardment, including most of the basin-forming impacts, was confined to a relatively brief "spike" at about $3.9 \mathrm{Ga}$. In an carlier paper [Dalrymple and Ryder, 1993] we reported our results on Apollo 15 impact melt rocks. In this paper we report the results of our study of Apollo 17 melt rocks and selected igneous clasts.

The early impact history of the lunar surface is important for understanding the evolution of both the primitive Moon and the corresponding populations of planetesimals in Earth-crossing, geocentric, and selenocentric orbits. There are two dissimilar end-member hypothesis for the early bombardment history of the lunar surface by large, basin-forming impactors that call for greatly different impact dynamics and account for the paucity of pre-4.0 Ga impact ages in quite different ways. The evidence and 
arguments for and against these two end-member hypotheses are discussed in our previous paper [Dalrymple and Ryder, 1993] and we will summarize them only briefly here. One hypothesis is that the Moon was subjected to a continuous heavy, though declining, bombardment by large impactors from about $4.5 \mathrm{Ga}$ to $3.9 \mathrm{Ga}$ while it was collecting material from its orbital path [e.g., Baldwin, 1974; Hartmann, 1975; Neukum, 1977; Wilhelms, 1987]. According to this hypothesis, the isotopic clocks were continually reset by succeeding impacts, and the abundance of $-3.9 \mathrm{Ga}$ highlands isotopic ages and the corresponding lack of pre-4.0 Ga ages merely reflects the final phase of the bombardment, primarily the Imbrium event [Baldwin, 1974, 1981, 1987a; Hartmann, 1975, 1980].

The other end-member hypothesis postulates an intense but brief bombardment at about $3.9 \mathrm{Ga}$ (the "terminal lunar cataclysm") that was responsible for producing most of the highlands landforms, including the lunar basins [Ryder, 1990; Tera et al., 1974]. Ryder [1990] noted that complete resetting of isotopic clocks requires complete or near melting conditions, whereas studies of terrestrial craters have shown that most impact ejecta are created and deposited cold. He also noted that the very existence of pre-4.0 Ga ages for highlands crustal rocks and mare basalts argues against complete or extensive impact resetting of the isotopic systems. Examining the existing geochronologic data, Ryder [1990] concluded that there is no convincing evidence for impact melt rocks older than about $3.9 \mathrm{Ga}$. The small number of reliable age data on impact melts and other ejecta are consistent with the hypothesis of the terminal lunar cataclysm and further suggests only light bombardment by basin-forming impactors during the first 600 m.y. of lunar history.

In contrast to its proponents, we argue that if the declining heavy bombardment hypothesis is correct, then the Ar isotopic systems of melt rocks should retain some record, even if imperfect, of those early basin-forming events. Reliable crystallization ages for impact melt rocks are needed to test this hypotheses and to refine the chronology of basin formation, yet few such data exist. In large part this is because melt rocks are usually contaminated with older clasts and commonly yield complex ${ }^{40} \mathrm{Ar} /{ }^{34} \mathrm{Ar}$ age spectra rather than straightforward plateau ages. Until recently, relatively large samples (tens to hundreds of milligrams) were required, making contamination of the melt rocks by clasts nearly impossible to avoid. In addition, pre- $1990^{40} \mathrm{Ar} /{ }^{39} \mathrm{Ar}$ age spectra typically contain few steps and are difficult to interpret because they lack detail and precision.

We are addressing the problem of the early impact history of the lunar surface by measuring ${ }^{41} \mathrm{Ar} /{ }^{39} \mathrm{Ar}$ age spectra for impact melt rocks using a continuous laser system that allows us to obtain high-resolution ${ }^{40} \mathrm{Ar} /{ }^{34} \mathrm{Ar}$ age spectra of $20-60$ steps on melt rock samples weighing as little as $0.060 \mathrm{mg}$; typical sample size is $\sim 0.5 \mathrm{mg}$. The use of this system on very small samples has several important advantages over other ${ }^{40} \mathrm{Ar} /{ }^{79} \mathrm{Ar}$ incremental heating methods, which typically require samples 100-1000 times larger. The most important advantage is that by careful sample selection and preparation, melt rock fragments devoid of older, contaminating clasts can be analyzed. A second advantage is that we can target single crystal or lithic clasts within the melt rocks. A third advantage is that the method conserves valuable lunar sample.

A primary goal of Apollo 17 was to collect samples of preImbrian highlands materials as far as possible from the effects of the Imbrium basin-forming event. From the pre-mission geological analysis it was expected that Serenitatis basin products would dominate the material that forms the massifs near the Apollo 17 site, but the presence of pre-Serenitatis ejecta and a thin cap of Imbrium and Crisium ejecta was also expected [NASA, 1973; Wilhelms, 1987; Wolfe et al., 1981].

The highlands rocks in the Apollo 17 collection are dominated by clast-bearing impact melts. Most of those that have been analyzed fall into two chemical and textural groups [Ryder, 1996; Spudis and Ryder, 1981]. The poikilitic melt rocks, which predominate, are relatively homogeneous in terms of chemical composition (Figure 1) and clast population. Many of the poikilitic melt rocks were sampled from boulders whose sources appear to be outcrops higher up on the South and North Massifs [Spudis and Ryder, 1981; Wolfe et al., 1981]. Because of their homogeneity, abundance, and provenance, the poikilitic melt rocks are commonly thought to represent samples of the Serenitatis melt sheet [Dymek et al., 1976; Spudis and Ryder, 1981; Warner et al., 1976; Winzer et al., 1977].

In contrast to the poikilitic melt rocks, the aphanitic melt rocks are chemically diverse (Figure 1), their clast populations differ from those of the poikilitic melt rocks, and the clasts are more varied in composition. In addition, the petrography of the aphanitic melts indicates that at least many are accretionary objects whereas the poikilitic melts lack accretionary features. Some workers have interpreted the aphanitic melt rocks as Serenitatis melt sheet material [Deuce et al., 1976; James et al., 1978; Warner et al., 1976; Wood, 1975]. For this to be true, their ages have to be the same as each other and the same as those of the poikilitic Serenitatis impact melts. Spudis and Ryder [1981] and Ryder [1996] have proposed that the diversity in composition and clast populations indicate that the aphanitic melt rocks are the product of either other basin-forming events, local impacts, or both.

About a dozen of the Apollo 17 poikilitic melt rocks have been studied previously by ${ }^{40} \mathrm{Ar} /{ }^{34} \mathrm{Ar}$ techniques (summarized by Wilhelms [1987]). The materials used for these earlier studies were primarily fragment-laden samples of the bulk melt rock weighing tens of milligrams, although some clasts and minerals (four samples) were also analyzed. The resulting ages range from $3.83 \mathrm{Ga}$ to $3.96 \mathrm{Ga}$, typically with large analytical errors, and some are difficult to interpret. (All ages cited in this paper have been recalculated, where necessary, with the new decay and abundance constants [Steiger and Jäger, 1977]. Sometimes this results in a rounding error of as much as $0.01 \mathrm{Ga}$. All errors in this paper are $2 \sigma$ ). Some of the age spectra from these samples are complex, but many, including those that represent the extremes of the age range, appear to have distinctive plateaus [e.g., Cadogan and Turner, 1976; Stettler et al., 1978].

The ${ }^{40} \mathrm{Ar} /{ }^{34} \mathrm{Ar}$ age data from the few aphanitic melt rocks that have been studied also provide a range of ages (3.86-4.17 Ga). Some of these ages are based on modeling of complex age spectra [e.g., Staudacher et al., 1979], some are based on total fusion results obtained by pulsed laser probe [e.g., Eichorn et al., 1979; Müller et al., 1977; Schaeffer et al, 1982a, b], and some are based on seemingly straightforward age spectrum plateaus [Leich et al., 1975; Staudacher et al., 1979]. All except the pulsed laser data were obtained on relatively large, fragment-laden, bulk samples.

After examining the published isotopic data, we concluded that the ages of the impacts that produced the poikilitic and aphanitic melt rocks have not been precisely or unambiguously determined and thus the age of the impact that formed the Serenitatis basin is also poorly known. Even the evidence for the 

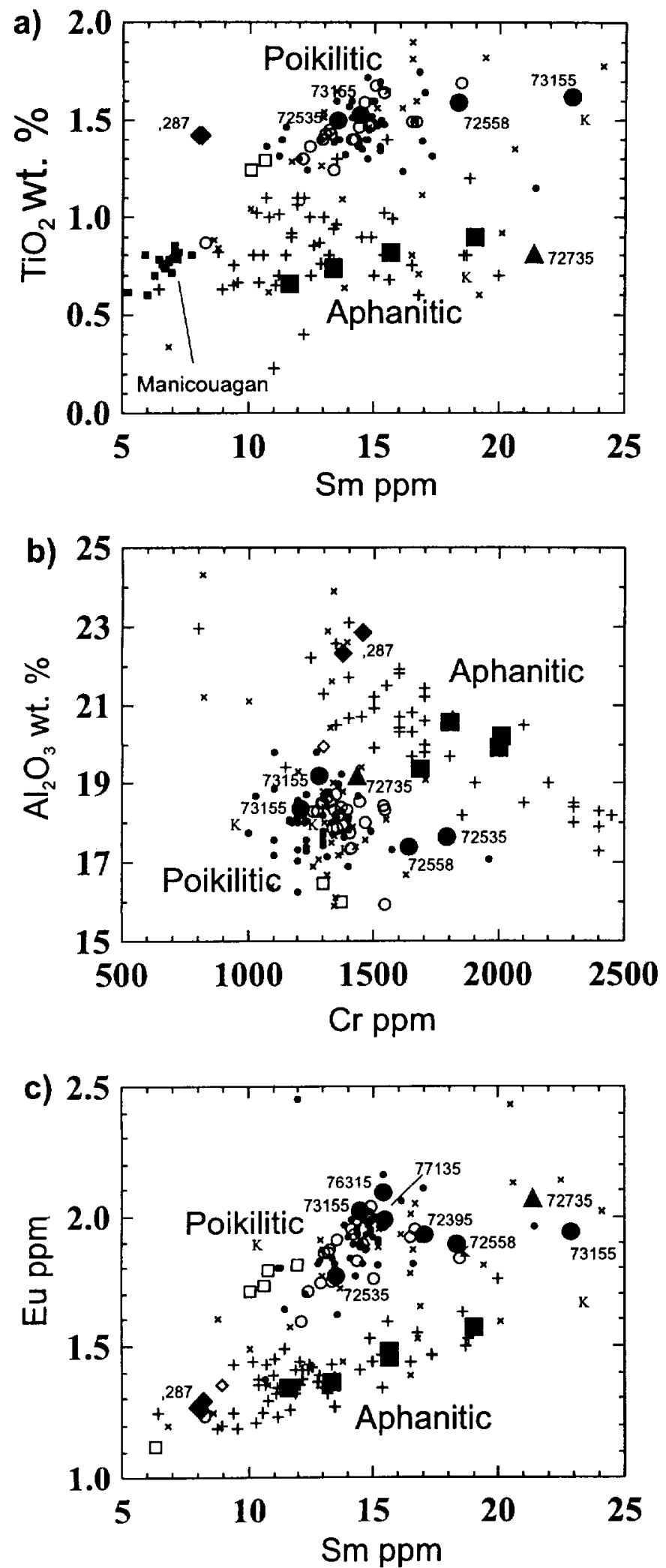

Figure 1. (a) $\mathrm{TiO}_{2}$ versus $\mathrm{Sm}$, (b) $\mathrm{Al}_{2} \mathrm{O}_{3}$ versus $\mathrm{Cr}$, and (c) $\mathrm{Eu}$ versus $\mathrm{Sm}$ for Apollo 17 impact melts including the melt samples analyzed in this study. A few are outside the boundaries of the figures. Our subsamples are shown as larger solid symbols (not all were analyzed for major elements): circles are Serenitatis, poikilitic melts (labeled); squares are aphanitic melts from 72255 (unlabeled); diamonds are the poikilitic clast in 72255 (labeled); relative age of Serenitatis with respect to many of the other nearside basins is poor. It is certainly older than the youngest basins (e.g., Orientale, Imbrium), but whether it is intermediate in age or ancient is uncertain (discussed more later).

The primary purpose of this work, in addition to our continuing search for pre-3.9 Ga impact melts, was to determine more precisely the age of Serenitatis and to clarify the age relations between the poikilitic and aphanitic melts. To this end we have measured ${ }^{40} \mathrm{Ar} /{ }^{39} \mathrm{Ar}$ age spectra on fourteen Apollo 17 impact melts whose petrography and chemical compositions are well characterized. We also measured age spectra on two gabbros enclosed in poikilitic melt in order to further constrain the age of the impact that produced the poikilitic melts. In addition, we have measured ${ }^{40} \mathrm{Ar} /{ }^{39} \mathrm{Ar}$ age spectra for three granulites to provide an independent upper age limit for the aphanitic melt in which two of them are enclosed and a lower limit for the age of the probable brecciation (impact) event that produced them. For all these samples we made chemical analyses on the splits allocated to us from which fragments for ${ }^{40} \mathrm{Ar}{ }^{31} \mathrm{Ar}$ analysis were taken.

\section{Description of Samples}

Poikilitic (Serenitatis) impact melt samples. The samples of micropoikilitic melt that are commonly accepted as derived from the Serenitatis event form a fairly tightly clustered chemical group (Figure 1). We selected five samples whose chemistry was already known to place them in that group, and our chemical analyses confirm the identity of our own subsamples. We selected one other melt sample because preliminary chemical data suggested that it was distinctly higher in potassium and thus probably not a Serenitatis melt (72558 [Warner et al., 1977]), but it was shown by our chemical analysis to be a typical Serenitatis melt (Figure 1).

Of the samples included in our study, 72395 (536 g), 76315 $(671 \mathrm{~g})$, and $77135(337 \mathrm{~g})$ were chipped from boulders; 72535 $(221 \mathrm{~g})$ and $72558(5.7 \mathrm{~g})$ were part of the raked collection; and $73155(79 \mathrm{~g})$ was an individually collected hand sample. Samples 76315 and 77135 are from the North Massif; the others are from the South Massif. All the samples are fine-grained

and the triangle is high-K melt 72735 (labeled). Previous analyses of Serenitatis melts are shown as small solid circles (most analyses) and open symbols (3-g samples of G. Ryder and K.R. Stockstill, in preparation, 1966). These together form a reasonable cluster, though not as tight as melt rocks from the Manicouagan crater (small squares, labeled) that are from much larger samples [Floran et al., 1978]. One of the 3-g samples is inexplicably distinct from the cluster that includes previous analyses of that sample. Previous analyses of aphanitic melt rocks are shown as crosses and form a loose elongate cluster distinct from the poikilitic, Serenitatis melts. Very few of the aphanite analyses are of splits larger than a few tens of milligrams and are more prone to clast variation than are the coarser, clast-poorer, poikilitic rocks. Our own analyses of five aphanitic melts from 72255 fall in this loose cluster. Other symbols are open squares for distinct samples $76055, \mathrm{~K}$ for $\mathrm{K}$-rich melt rocks, and small croses that are varied analyses of melt particles by B.L. Jolliff et al. (personal communication, 1996) that are not distinguished in type here. 
poikilitic impact melt breccias; descriptions and references for the individual samples are provided by Ryder [1993] and Meyer [1994]. Sample 77135 is the coarsest grained of our samples, with some oikocrysts exceeding $1 \mathrm{~mm}$ diameter. It is conspicuously vesicular. Sample 73155 is the finest grained, with groundmass phases equigranular and less than $20 \mu \mathrm{m}$; oikocrysts are little developed. All of the samples contain less than about $15 \%$ clastic material, with the coarser-grained rocks containing the least. Very little of the fragmental material is more than a millimeter across, although some larger clasts do exist (for instance, 72395 is the host for dunite 72415 , and 77135 is the host for a very large norite). However, fine-grained clastic material is ubiquitous in all these rocks, so that even submillimeter subsamples contain numerous tiny fragments; these are more common in the finer-grained rocks. Nonetheless, these smaller clastic fragments can be expected to have degassed more completely during melt formation than larger fragments.

Of the Serenitatis samples included in our study, only 76315 and 77135 had previous ${ }^{40} \mathrm{Ar} /{ }^{34} \mathrm{Ar}$ age spectra for the groundmass material [Stettler et al., 1974, 1975; Tumer and Cadogan, 1975]. We included these samples for the purpose of comparison and to see if an increased number of release steps and a smaller subsample could provide greater insight into the release structure and perhaps provide an age for the crystallization of the 77135 groundmass, which had failed to provide an age spectrum plateau.

Gabbro sample in Serenitatis impact melt 73155. The gabbro (in the strict sense) clast in 73155 is an unusual lithic type that occurs as schlieren or fragmented clastic material up to about $8 \mathrm{~mm}$ long [Ryder, 1992b]. It consists dominantly of sodic plagioclase, iron-rich clinopyroxene, and an interstitial glass. The clinopyroxene, some of which shows thin exsolution lamellae, is both zoned and riddled with inclusions of sulfide and silicic glass with potash feldspar. The grain size of the original lithology was about $1 / 2$ to $1 \mathrm{~mm}$. A pure separation for chemical analysis is probably not possible because the groundmass pervades the clast. Thus the chemical analysis in Table 1 may not be entirely representative, and the sample analyzed contains significant $\mathrm{Ni}, \mathrm{Co}$, and Au suggestive of meteoritic and thus matrix contamination. While the gabbro contains high $\mathrm{K}_{2} \mathrm{O}, \mathrm{Rb}$, and $\mathrm{Cs}$, consistent with the presence of interstitial $\mathrm{Si}-\mathrm{K}$ rich glass, most of its incompatible element abundances are much lower than the Serenitatis impact melts. The rare earth element pattern is fairly flat, with a small positive Eu abundance. Given the small size of the sample analyzed, it is not apparent whether the analysis shows that the gabbro itself is unusually depleted in the rare earths or whether the analysis suffers by the likely chance of not including adequate sparse phosphate grains. However, considering that the rare earth pattern is actually flat (not a likely result of mixtures of cumulus phases from a magma, especially one without a flat pattern itself) and the lack of phosphate phases in the thin sections, there is a strong suggestion that this is an iron-rich gabbro with unusually unevolved trace element chemistry.

While the crystallization age of the gabbro is intrinsically significant in lunar history, we included it primarily because of the possibility that degassing during the Serenitatis impact event, in particular of its potassic glassy material, might provide a further constraint on the age of that event. For this particular objective, some matrix contamination would not be significant.

Aphanitic melts from 72255. Sample 72255 was collected as a matrix sample of the layered Boulder 2 at Station 2, on the South Massif landslide [Marvin, 1975; Ryder et al., 1975]. It contains numerous dark gray aphanitic blobs or clasts in its own gray aphanitic matrix; the blobs have boundaries that range from sharp to gradational. The dark gray blobs contain few macroscopically visible clasts other than tiny plagioclase grains. The matrix groundmass and the blobs are petrographically similar and consist of fine-grained to cryptocrystalline or glassy melt with numerous tiny clasts, mainly silicate minerals, but including lithic clasts of great variety.

The blobs range from a few tens of microns up to several centimeters, and some are schlieren. Our samples were selected as part of a broader petrographic and chemical study of 72255 (G. Ryder and K. Kuebler, manuscript in preparation, 1996], and were taken following mapping of sawn surfaces. The chemical analyses of all five dark gray blobs studied here are similar but not identical, and an average is given in Table 1; this average is similar to the bulk composition of the rock and the matrix as determined in previous studies [e.g., Blanchard et al., 1975; Palme et al., 1978]. On petrographic and chemical grounds, it seems likely that the blobs or clasts are cogenetic with each other and the matrix. Their composition is more similar to that of other aphanites than it is to the Serenitatis impact melt composition (Figure 1).

The fine-grained and clast-rich groundmass of the 72255 aphanitic phases create difficulties for argon age determinations because the rapidly cooled melt may not have been adequately degassed originally, the analyses are compromised by the abundant and ubiquitous plagioclase clasts that may not have degassed, and those same clasts may produce a greater recoil effect (an analytical artifact) than in coarser-grained, clast-poorer samples. Leich et al. [1975] made Ar-Ar age determinations on aphanite from 72255. It is not clear what the significance of the "age" of their three-step intermediate age plateau actually is, although both Leich et al. [1975] and Schaeffer et al. [1982a, b] inferred ages for aphanite from 72255 and these will be discussed later.

Poikilitic melt within $\mathbf{7 2 2 5 5}$ aphanitic melt. A poikilitic impact melt fragment, at least $7 \mathrm{~mm}$ in diameter, in 72255 has a chemical composition distinct from other Apollo 17 impact melt fragments, including the Serenitatis poikilitic impact melts and the aphanitic melt that dominates 72255 itself. It is more aluminous and contains a lower abundance of the incompatible trace elements (Table 1). The petrography of the fragment is similar to the Apollo 17 and Apollo 16 poikilitic impact melts, but it contains more clinopyroxene as oikocrysts, which are about a millimeter across [Ryder, 1992a].

Apart from being an impact melt in its own right and thus potentially a recorder of the age of a lunar impact event, the poikilitic melt clast was included in our study because being immersed in and thus older than the 72255 aphanitic melt, it has the potential to provide an upper limit on the age of the 72255 aphanitic melt-producing event and thus provide useful information about the age relationship of the aphanitic and the poikilitic (Serenitatis) melts.

Other Apollo 17 melts. Sample 72735 is a high-K, finegrained, clast-bearing impact melt. It has a greater proportion of clastic material (about 20-25\%) than most nonaphanitic impact melts at the Apollo 17 landing site. Our analysis (Table 1) confirms the previous conclusion that it is substantially more potassic and somewhat more enriched in other incompatible elements than other Apollo 17 impact melt rocks [Murali et al., 1977; Warner et al., 1977]. The high potassium is not a result of the greater abundance of clastic material, which is dominantly feld- 


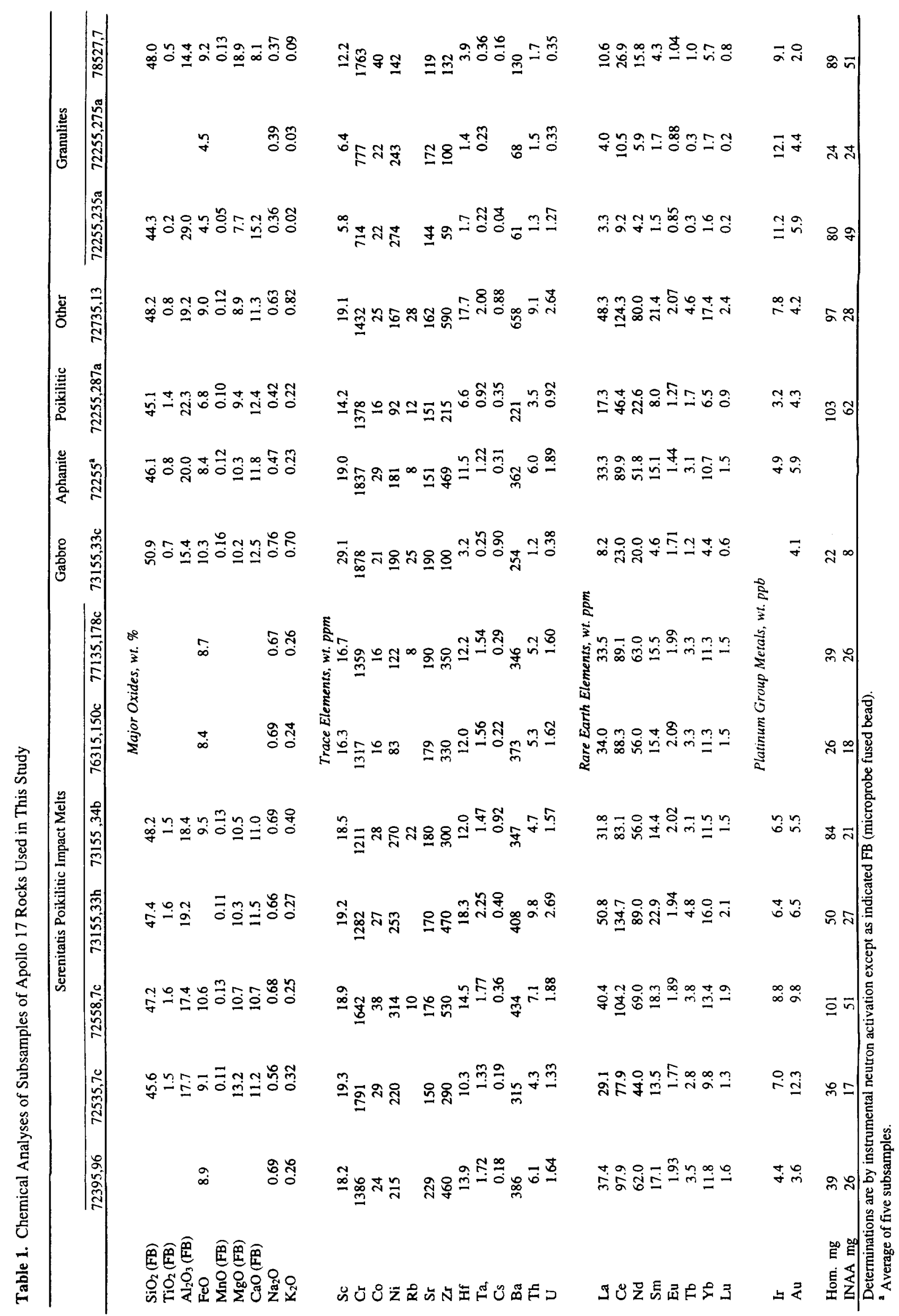


spathic [Warner et al., 1977]. Thus there is the potential that 72735 was created in an impact event distinct from any of the other impact melts recognized among Apollo 17 samples.

Granulites. The two fragments from 72255 are similar to each other in chemical composition and are feldspathic with low abundances of incompatible elements (Table 1). No thin section of 72255,275 was made, but 72255,235 is a fine-grained feldspathic granulite with $75-80 \%$ plagioclase, tiny mafic silicates, and some oxides, not unlike other feldspathic granulites observed in 72255 and other Apollo 17 impact melt rocks. Sample 78527 is quite different (Table 1), and our analysis confirms previous analyses [Laul and Schmitt, 1975; Murali et al., 1977; Warren et al., 1983] that it is a norite in composition (only about $15 \mathrm{wt} . \%$ $\mathrm{Al}_{2} \mathrm{O}_{3}$ ). Although it has a composition similar to the pristine norite 78255 also found at Station 8 , it has comparatively elevated incompatible elements. It also has a recrystallized matrix [Nehru et al., 1978], and it has been included as a granulite in the study by Cushing et al. [1966]. Our analysis confirms that 78527 , unlike the pristine norite 78255 , has meteoritic contamination in the form of elevated Ir and Au (Table 1).

We included the two 72255 samples in our study because as clasts their ages can help to provide an upper limit for the age of their aphanite host. The ages of these granulites, as well as the age of granulite 78527 , also can provide a lower limit for the age of the probable brecciation (impact) event that produced them. Such brecciation events might date back to the accretionary bombardment of the Moon.

\section{Analytical Methods}

The samples chosen for chemical analysis and for laser ${ }^{40} \mathrm{Ar} /{ }^{39} \mathrm{Ar}$ studies were inspected in the curatorial laboratory. Representative chips, avoiding obvious large clasts and adhering patina and dust, were selected for allocation. For some samples, entirely avoiding saw-cut surfaces was not possible. The allocated chips ranged from as small as $30 \mathrm{mg}$ to as large as $200 \mathrm{mg}$ (hence smaller than a few millimeters).

The samples were processed in the clean neutron activation preparation room at the Johnson Space Center, using agate and sintered sapphire mortars and pestles. The samples were gently crushed and then picked to separate as much as possible any sawn surfaces, patina, and large clasts that had been unavoidable in the original selection. For sample 73155,33 the allocated pieces had been selected specifically to obtain samples of the gabbro clasts. Further "high-grading" was performed in the clean room, attempting to separate gabbro and melt groundmass. This was impossible to complete satisfactorily because of the penetration of gabbro by melt. From each sample a few representative small fragments, generally totaling less than $5 \mathrm{mg}$, were selected for ${ }^{40} \mathrm{Ar} /{ }^{39} \mathrm{Ar}$ analysis.

The remainder of each sample, except for the picked minerals, those fragments with surficial contamination, and in a few cases some material kept in reserve, was ground to a fine powder. In most cases, about 10-20 mg was used to make a glass bead by fusing powder on a molybdenum strip in an $\mathrm{Ar}$ atmosphere [Brown, 1977], but this was not done for those samples with little mass. The glass beads were analyzed for major elements using the Cameca microprobe at the Johnson Space Center. Standard procedures and techniques were used, with an accelerating voltage of $15 \mathrm{kV}$ and a beam current of around $25 \mathrm{nA}$. These data are included in Table 1. The remainder of the powder was subjected to instrumental neutron activation analysis at the Johnson
Space Center, using standard procedures and data reduction [e.g., Lindstrom et al., 1989]. These data are also included in Table 1, which lists the mass of sample homogenized and the mass used for neutron activation. For the purposes of this paper, these sample sizes are perfectly adequate for chemical characterization because of the fine grain size of the samples, and good comparisons exist for those samples analyzed previously (e.g. 72395).

Fragments selected for ${ }^{40} \mathrm{Ar} /{ }^{34} \mathrm{Ar}$ analyses were encapsulated in small, stacked $\mathrm{Al}$ cups, one lunar sample per cup, and irradiated in three separate irradiations. Approximately two dozen hand-picked crystals of MMhb-1 hornblende, the neutron fluence monitor mineral (513.9 Ma [Lanphere et al., 1990]), were included in each cup. Irradiation \#113 was for 115 hours (fast neutron dose of approximately $2 \times 10^{19} \mathrm{nvt}$ ) in the hydraulic rabbit (core position E-3) facility of the Omega West Reactor at Los Alamos National Laboratory. Irradiation \#119 was for 340 hours (fast neutron dose of approximately $1.2 \times 10^{14} \mathrm{nvt}$ ) in core position L67 of the Ford Reactor at the University of Michigan. Irradiation \#126 was for 34 hours (fast neutron dose of approximately $1.2 \times 10^{19} n v t$ ) in core position V15 of the High Flux Beam Reactor at Brookhaven National Laboratory. The neutron efficiency factor $J$ for each irradiated lunar sample was calculated from six measurements of three to four grains (18-20 grains total) of the monitor mineral each for each irradiated lunar sample. The precision of $J$ is approximately $0.5 \%$.

As in our Apollo 15 study [Dalrymple and Ryder, 1993] a fragment of Apollo 15 melt rock $(15304,7,69)$ was included in each irradiation in order to provide an independent cross-check on the interirradiation precision of $J$ (Table 2). For irradiations 119 and 126 the ${ }^{40} \mathrm{Ar} /{ }^{34} \mathrm{Ar}$ plateau ages for this sample were 3874 $\pm 16 \mathrm{Ma}$ and $3878 \pm 16 \mathrm{Ma}$, both of which are within the range of the five values (3856-3879 $\mathrm{Ma}$ ) measured for this sample in our three Apollo 15 irradiations. For irradiation \#113 the plateau age obtained for $15304,7,69$ was $3906 \pm 16 \mathrm{Ma}$. The age spectrum, however, differed significantly in shape from those typical of the sample, and the K/Ca spectrum is entirely dissimilar. We think that this particular fragment was contaminated by a clast that not only changed the shape of the release patterns but increased the age as well. Thus we do not interpret this older age for $15304,7,69$ as indicating a systematic age offset for the other samples in irradiation 113 .

The monitor minerals and the melt rock fragments were measured with the GLM (Great Little Machine) ${ }^{410} \mathrm{Ar} /{ }^{34} \mathrm{Ar}$ laser system [Dalrymple, 1989; Dalrymple and Duffield, 1988], which consists of a 5-W continuous Ar-ion laser, beam steering and focusing optics, a small sample chamber, $\mathrm{Zr}$-Al getters, and a Mass Analyzer Products model 216 mass spectrometer equipped with a Baur-Signer source and 20-stage electron multiplier. The melt rock fragments were each placed in small wells in a copper planchet where they were heated for $60 \mathrm{~s}$ at each temperature by directing the broadened and slightly defocused laser beam through the sapphire window of the sample chamber. Hall [1990] has shown that temperature gradients within small samples heated in this way are negligible. Temperature was measured with a Minarad model MR-100 infrared microscopic radiometer. Emissivity for the melt rock fragments was estimated at 0.87 , so the measured temperatures are not necessarily accurate.

Corrections for interfering $\mathrm{Ar}$ isotopes produced by undesirable reactions with $\mathrm{Ca}$ and $\mathrm{K}$ were determined for the Los Alamos and Brookhaven reactors using optical grade $\mathrm{CaF}_{2}$ and artificial kalsilite glass. Corrections for the Michigan reactor were determined and provided by C.M. Hall (personal communication, 
Table 2. Summary of ${ }^{40} \mathrm{Ar} /{ }^{39} \mathrm{Ar}$ Incremental Heating Results on Apollo 17 Impact Melt Rocks

\begin{tabular}{|c|c|c|c|c|c|c|c|c|}
\hline \multirow[t]{2}{*}{ Sample } & \multirow[t]{2}{*}{ Description } & \multirow[t]{2}{*}{ Irradiation } & \multirow{2}{*}{$\begin{array}{c}\text { Weight, } \\
\text { mg }\end{array}$} & \multirow{2}{*}{$\begin{array}{l}\text { Total Gas } \\
\text { Age, }{ }^{\mathrm{b}} \mathrm{Ma}\end{array}$} & \multirow{2}{*}{$\begin{array}{c}\text { Plateau } \\
\text { Description }\end{array}$} & \multicolumn{2}{|c|}{ Plateau ${ }^{39} \mathrm{Ar}$} & \multirow{2}{*}{$\begin{array}{l}\text { Age }^{b} \\
(\mathrm{Ma})\end{array}$} \\
\hline & & & & & & Percent & Steps & \\
\hline $72255,235 \mathrm{~B}$ & granulite & 119 & 0.280 & $3853 \pm 16$ & fair & 63 & 19 of 42 & $3850 \pm 16$ \\
\hline $72255,238 \mathrm{~B}$ & aphanitic melt & 126 & 0.684 & $3805 \pm 16$ & good & 47 & 16 of 50 & $3869 \pm 16$ \\
\hline $72255,248 B$ & aphanitic melt & 126 & 1.340 & $3806 \pm 16$ & good & 26 & 17 of 63 & $3883 \pm 16$ \\
\hline $72255,255 \mathrm{~B}$ & aphanitic melt & 119 & 1.068 & $3803 \pm 16$ & good & 79 & 30 of 50 & $3867 \pm 16$ \\
\hline $72255,256 \mathrm{~B}$ & aphanitic melt & 119 & 0.630 & $3675 \pm 16$ & none & 10 & 7 of 54 & $\geq 3894$ \\
\hline $72255,275 B$ & granulite & 126 & 0.853 & $3873 \pm 16$ & fair & 44 & 36 of 50 & $3861 \pm 16$ \\
\hline $72255.282 \mathrm{~B}$ & aphanitic melt & 126 & 1.530 & $3912 \pm 16$ & good & 28 & 2 of 47 & $3951 \pm 17$ \\
\hline \multirow[t]{2}{*}{$72255,287 \mathrm{~B}$} & poikilitic melt & 113 & 0.740 & $3719 \pm 16$ & poor & 18 & 10 of 39 & $3835 \pm 16$ \\
\hline & & 113 & 0.451 & $3730 \pm 16$ & poor & 9 & 8 of 36 & $3851 \pm 16$ \\
\hline $72395,96 \mathrm{~A}$ & poikilitic melt, Serenitatis & 113 & 0.529 & $3870 \pm 16$ & good & 36 & 20 of 55 & $3893 \pm 16$ \\
\hline $72535,7 \mathrm{~A}$ & poikilitic melt, Serenitatis & 119 & 0.703 & $3849 \pm 16$ & good & 31 & 18 of 48 & $3887 \pm 16$ \\
\hline $72558,7 \mathrm{~A}$ & poikilitic melt, Serenitatis & 113 & 0.561 & $3721 \pm 16$ & poor/none & 25 & 14 of 48 & $\geq 3869$ \\
\hline $72735,13 \mathrm{~A}$ & High-K melt & 113 & 0.481 & $3539 \pm 16$ & none & 0 & 0 of 50 & $\geq 3846$ \\
\hline $73155,33 \mathrm{~A}$ & gabbro clașt & 119 & 0.870 & $3672 \pm 16$ & poor & 17 & 4 of 35 & $3865 \pm 16$ \\
\hline $73155,33 \mathrm{~B}$ & gabbro clast & 126 & 0.322 & $3769 \pm 16$ & good & 47 & 24 of 61 & $3900 \pm 16$ \\
\hline $73155,3,3 \mathrm{E}$ & poikilitic melt, Serenitatis & 119 & 0.489 & $3807 \pm 16$ & good & 34 & 10 of 42 & $3854 \pm 16$ \\
\hline $73155,34 \mathrm{~A}$ & poikilitic melt, Serenitatis & 126 & 0.474 & $3914 \pm 16$ & poor/none & 22 & 12 of 48 & $3937 \pm 16$ \\
\hline $76315,150 \mathrm{~A}$ & poikilitic melt, Serenitatis & 113 & 0.620 & $3886 \pm 16$ & good & 34 & 14 of 38 & $3900 \pm 16$ \\
\hline $77135,178 \mathrm{~A}$ & poikilitic melt, Serenitatis & 113 & 0.418 & $3444 \pm 16$ & none & 0 & 0 of 27 & $\geq 3743$ \\
\hline $78527,6 \mathrm{~A}$ & granulite & 126 & 0.462 & $4001 \pm 16$ & fair & 23 & 4 of 21 & $4146 \pm 17$ \\
\hline $15304,7,69$ & melt rock & 113 & 0.181 & $3857 \pm 16$ & $\operatorname{good}$ & 41 & 9 of 25 & $3906 \pm 16$ \\
\hline $15304,7,69$ & melt rock & 119 & 0.741 & $3857 \pm 16$ & $\operatorname{good}$ & 59 & 22 of 59 & $3874 \pm 16$ \\
\hline $15304,7,69$ & melt rock & 126 & 0.481 & $3859 \pm 16$ & good & 47 & 23 of 59 & $3878 \pm 16$ \\
\hline
\end{tabular}

Analytical data, including reactor corrections and corrections for cosmogenic and trapped Ar are available from the AGU microforms repository. All age spectra, except those for 72535,7A (shown by Dalrymple and Ryder [1996]) and the 0.451 fragment of 72255,287B, are shown in Figures 2-4.

a Analyses were on single rock fragments.

${ }^{\mathrm{b}} \lambda_{\varepsilon}=0.581 \times 10^{-10} \mathrm{yr}^{-1}, \lambda_{\beta}=4.962 \times 10^{-10} \mathrm{yr}^{-1}$. Weighted mean and $2 \sigma_{\text {best }}$ error [Taylor, 1982] for age spectra, $2 \sigma$ errors for total gas age.

1993). The corrections for trapped Ar isotopes are the solar values, while those for cosmogenic Ar isotopes are from Hohenberg [1978]; atmospheric Ar is assumed to be negligible. The Ar isotope ratios were corrected for the system blank using the results of blank runs made at the beginning of the day and after every four to six temperature steps. All of the corrections are known with sufficient precision that they contribute negligible error to the age calculations for the lunar samples we analyzed'.

Plateau ages are expressed as the weighted mean of the plateau increments and its weighted error at the $95 \%$ level of confidence $\left(2 \sigma_{\text {tee }}[\right.$ Taylor, 1982]). We have been conservative in selecting plateaus, choosing to exclude steps rather than to include them if there is doubt. In general, however, the age spectra are sufficiently detailed that the inclusion or exclusion of one or more steps in a plateau has little or no effect on the weighted mean plateau age.

Total gas ages were calculated by summing the Ar data from each step. This results in the age that would have been obtained had the sample been fused in a single step.

$\mathrm{K} / \mathrm{Ca}$ spectra were calculated from the incremental release of the ${ }^{39} \mathrm{Ar}$ generated by neutron reactions with ${ }^{39} \mathrm{~K}$, and the ${ }^{37} \mathrm{Ar}$ generated by neutron reactions with ${ }^{40} \mathrm{Ca}$. These spectra have errors in accuracy of as much as $30 \%$, but the errors in the ratios between individual increments within an age spectrum are generally precise within a few percent. The spectra can be used to determine whether high $\mathrm{K} / \mathrm{Ca}$ phases or low $\mathrm{K} / \mathrm{Ca}$ phases are pro-

\footnotetext{
'Analytical data and correction factors are available with entire article on microfiche. Order by mail from American Geophysical Union, 2000 Florida Avenue, N.W., Washington, DC 20009, or by phone at 800-9662481; $\$ 2.50$. Document E96-001. Payment must accompany order.
}

viding the bulk of the Ar released in the individual temperature steps.

\section{Results}

The ages and $\mathrm{K} / \mathrm{Ca}$ spectra we obtained for the Apollo 17 samples are shown in Figures 2-4 and summarized in Table 2. The age spectrum for sample $72535,7 \mathrm{~A}$ is not shown in the figures but is shown by Dalrymple and Ryder [1996]; it is otherwise included in this paper for completeness. Temperatures $T$ are not shown on the age spectra because they have no quantitative significance, but in our discussion of the spectra we describe them in terms of their low- $T\left(-450^{\circ}-800^{\circ} \mathrm{C}\right)$, intermediate- $T$ $\left(800^{\circ}-950^{\circ} \mathrm{C}\right)$, and high- $T$ ( $~ 950^{\circ} \mathrm{C}$-fusion) portions corresponding to low $(\sim 0-25 \%)$, intermediate $(-25-75 \%)$, and large $(\sim 75-100 \%)$ percentages of ${ }^{34} \mathrm{Ar}$ released, respectively. In general, the age spectrum plateaus obtained for the Apollo 17 samples are smaller (i.e., expressed by less ${ }^{34} \mathrm{Ar}$ released) and are expressed at somewhat lower temperatures than those for our Apollo 15 samples. Even though some of the Apollo 17 intermediate- $T$ plateaus extend into the low- $T$ range, we refer to them in this paper as intermediate- $T$ plateaus for simplicity.

Some of our age spectra on the melt rocks show the effects of ${ }^{34} \mathrm{Ar}$ recoil, which is common in fine-grained lunar samples (e.g., Figures $2 \mathrm{a}$ and $2 \mathrm{e}$ ). This phenomenon usually causes anomalously high ages in some of the earliest, low- $T$ increments $(0-15 \%$ ${ }^{39} \mathrm{Ar}$ released) and anomalously low ages in the later, high- $T$ increments ( $>50 \%{ }^{39} \mathrm{Ar}$ released). Theory and laboratory experiments show that this is caused by recoil out of fine-grained, $\mathrm{K}$ rich phases of ${ }^{39} \mathrm{Ar}$ during its creation by nuclear reactions in the irradiation and its subsequent implantation into more refractory and more retentive phases with lower $\mathrm{K} / \mathrm{Ca}$ [Huneke and Smith, 

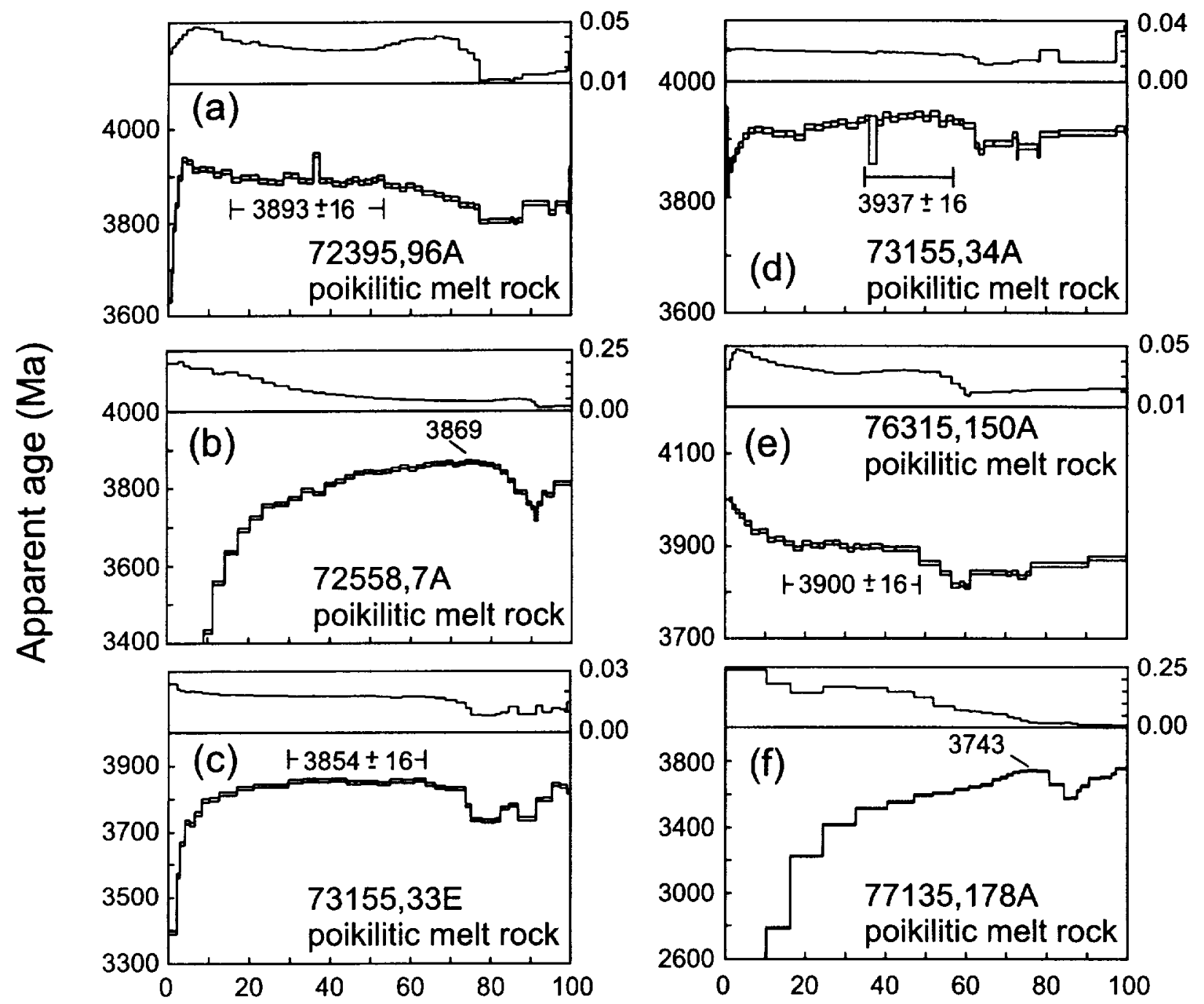

\section{${ }^{39} \mathrm{Ar}$ released $(\%)$}

Figure 2. The ${ }^{41} \mathrm{Ar} /{ }^{3 y} \mathrm{Ar}$ age spectra of Apollo 17 poikilitic melt rocks measured by laser incremental heating. The bars indicate the apparent ages of the individual increments. Half of the vertical dimension of the bars is the estimated standard deviation of precision of the increment age. The plateau ages are weighted means $\pm 2 \sigma_{\text {mext }}$. The $\mathrm{K} / \mathrm{Ca}$ values were calculated from the ${ }^{39} \mathrm{Ar} /{ }^{37} \mathrm{Ar}$ ratios.

1976; Turner and Cadogan, 1974]. Recoil also affects the ${ }^{39} \mathrm{Ar} /{ }^{37} \mathrm{Ar}$ ratios and hence the $\mathrm{K} / \mathrm{Ca}$ values calculated from these $\mathrm{Ar}$ isotope ratios. For this reason the $\mathrm{K} / \mathrm{Ca}$ ratios calculated from the "recoil steps" may have only qualitative compositional significance.

It is usually assumed that the recoil phenomenon has no effect on intermediate- $T$ plateaus and that the plateaus record crystallization and cooling ages in these fine-grained lunar samples. One reviewer of this paper suggested, however, that several of the plateau ages reported here (for samples 72395,96A, 72535,7A, $76315,150 \mathrm{~A}$, and possibly $73155,34 \mathrm{~A}$ and $73155,33 \mathrm{E}$ ) might be too high because of recoil of ${ }^{34} \mathrm{Ar}$ from the plateau increments. His reasoning is that the disturbance in the low- $T$ increments of the age spectra of these samples seems inadequate to account for the disturbance in the high- $T$ increments, i.e., that there is a mass imbalance between the ${ }^{34} \mathrm{Ar}$ lost by recoil (low- $T$ ) and ${ }^{39} \mathrm{Ar}$ gained by implantation (high- $T$ ). The reviewer suggested that the total gas ages might more accurately reflect the crystallization ages of these samples. While the reviewer's hypothesis is possible, we think it is unlikely for several reasons. First, because the low-T increments in these fine-grained lunar samples are commonly the result of both thermal loss of ${ }^{41} \mathrm{Ar}$ and loss of ${ }^{39} \mathrm{Ar}$ by recoil, which have opposite effects, it is not possible to determine whether or not there is a ${ }^{39} \mathrm{Ar}$ imbalance. Second, this would require either that the ${ }^{34} \mathrm{Ar}$ loss be quantitatively uniform across the plateau increments in order to preserve the appearance of a preexisting plateau or that the ${ }^{34} \mathrm{Ar}$ loss be exactly that required to create a plateau where none existed prior to irradiation, both of which are highly unlikely. Finally, because some of the ${ }^{~} \mathrm{Ar}$ lost by recoil is not implanted but instead escapes from the rock [Turner and Cadogan, 1974] and because most lunar samples suffer from some thermal loss of ${ }^{40} \mathrm{Ar}$, total gas ages are a highly 
unreliable indicator of crystallization age. In this paper therefore, we adopt the more conventional interpretation that intermediate- $T$ plateau ages represent crystallization ages.

The following description of results is organized numerically by sample number. The significance of the results, by type of sample, is discussed in the following section.

Sample 72255,235B (granulitic). The age spectrum for this granulite shows evidence of Ar loss by heating, particularly in the low- $T$ increments (Figure 4a); recoil effects are not evident. It has a substantial if somewhat irregular intermediate- $T$ plateau at $3850 \pm 16 \mathrm{Ma}$. The irregularity in the plateau is due to the relatively small size of the fragment analyzed and the low $\mathrm{K}$ of the sample (the combination of which resulted in very small amounts of $\mathrm{Ar}$ in each increment) and the resulting effect of small errors in the instrumental background corrections. The higher- $T$ increments have apparent ages that exceed $3900 \mathrm{Ma}$. These are from the lowest $\mathrm{K} / \mathrm{Ca}$ phases, presumably the more anorthitic plagioclase cores. This age spectrum indicates that the granulite crys- tallized prior to $3900 \mathrm{Ma}$, was later affected by a major heating (impact) event, and subsequently cooled at about $3850 \mathrm{Ma}$.

Sample 72255,238B (aphanitic). The age spectrum of this aphanitic melt rock (Figure $3 a$ ) has a good high temperature plateau at $3869 \pm 16 \mathrm{Ma}$. The early increments show some Ar loss by reheating. The age spectrum has an intermediate $T$ peak at about $30-40 \%{ }^{34}$ Ar released followed by a drop in apparent ages, then an increase in apparent ages to the plateau. We have not seen a spectrum like this before and are unsure of its cause, although the drop in apparent ages at $40-50 \%{ }^{34}$ Ar released may be due to recoil expressed at intermediate $T$, rather than high $T$. We interpret the high- $T$ plateau of $3869 \mathrm{Ma}$ as a crystallization age.

Sample 72255,248B (aphanitic). The age spectrum for this fragment (Figure 3b) of aphanitic melt rock shows substantial effects of Ar loss by reheating in the early increments but climbs to a plateau at $3883 \pm 16 \mathrm{Ma}$ between $50 \%$ and $75 \%{ }^{34} \mathrm{Ar}$ released. The increments above the plateau show a small decrease in age followed by an increase, which is indicative of ${ }^{34}$ Ar recoil. The
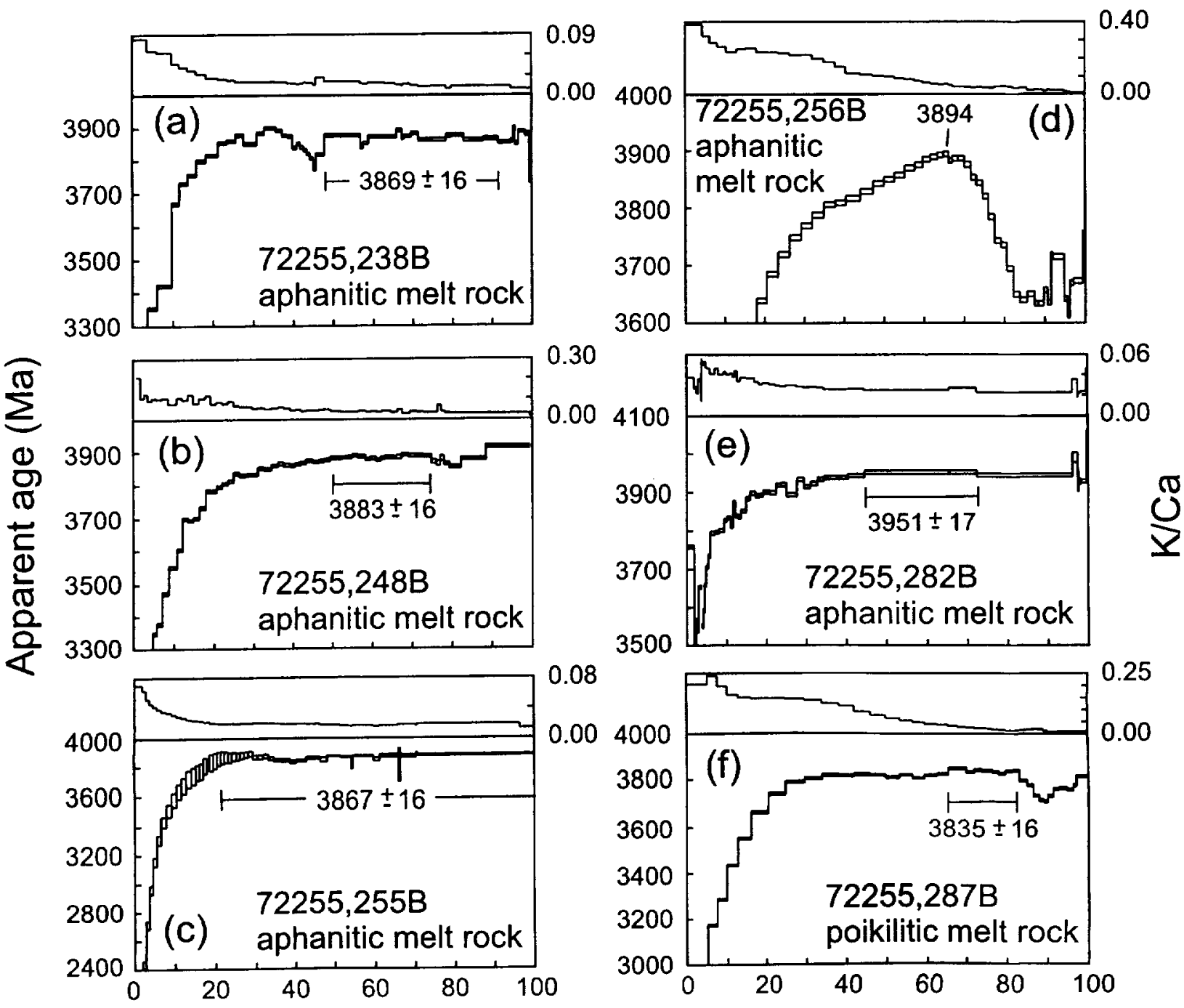

${ }^{39}$ Ar released $(\%)$

Figure 3. The ${ }^{40} \mathrm{Ar} f^{34} \mathrm{Ar}$ age spectra, measured by laser incremental heating, of Apollo 17 aphanitic melt rocks and a poikilitic melt rock enclosed within aphanitic melt. Explanation as in Figure 2. 
recoil effects are not evident in the low-T steps because they have been masked by the larger effects of Ar loss by reheating. We interpret the plateau age of $3883 \mathrm{Ma}$ as a crystallization age.

Sample 72255,255B (aphanitic). This aphanitic melt rock has a intermediate- and high- $T$ plateau that includes nearly $80 \%$ of the ${ }^{39} \mathrm{Ar}$ released and indicates a crystallization age of $3867 \pm$ $16 \mathrm{Ma}$ (Figure 3c). The samples shows signs of minor low- $T{ }^{39} \mathrm{Ar}$ loss, probably due to thermal effects, and no indications of recoil.

Sample 72255,256B (aphanitic). This aphanitic melt rock does not have a plateau and the age spectrum shows that the sample underwent substantial thermal loss of $\mathrm{Ar}$ (Figure 3d). It also shows significant effects of ${ }^{34} \mathrm{Ar}$ recoil in the high- $T$ part of the spectrum. The corresponding recoil effects in the low- $T$ increments have been masked by thermal Ar loss. The age spectrum reaches a maximum of $3894 \mathrm{Ma}$, which we interpret as a minimum age for the formation of this melt rock and its oldest clasts.

Sample 72255,275B (granulitic). The age spectrum of this granulite fragment has a low- to intermediate- $T$ plateau at $3861 \pm$ $16 \mathrm{Ma}$ that includes $44 \%$ of the ${ }^{34} \mathrm{Ar}$ released (Figure $4 \mathrm{~b}$ ). The sample shows slight effects of thermal Ar loss in the lowest- $T$ increments. The high- $T$ increments increase and reach a maximum of $3919 \mathrm{Ma}$. There is no indication of ${ }^{39} \mathrm{Ar}$ recoil. The age spectrum for this sample resembles that of the other feldspathic granulite analyzed, $72255,235 \mathrm{~B}$. The plateau ages of these two samples are not significantly different at the $95 \%$ level of confidence and their chemical compositions are similar, suggesting a common source lithology.

Sample 72255,282B (aphanitic). The age spectrum of this aphanitic melt rock has a plateau that includes more than half of the ${ }^{3 y} \mathrm{Ar}$ released (Figure 3e). The plateau, however, decreases slightly at the higher temperature steps. We have been conservative and selected the two highest steps to represent the plateau age. This age, which we interpret as the crystallization age, is $3951 \pm 17 \mathrm{Ma}$. If all of the high- $T$ steps are included, the plateau age is $3944 \pm 16 \mathrm{Ma}$.

Sample 72255,287B (poikilitic). This sample of poikilitic melt, which was enclosed within aphanitic melt, has a relatively small plateau that includes $18 \%$ of the ${ }^{34} \mathrm{Ar}$ released (Figure $3 \mathrm{f}$ )

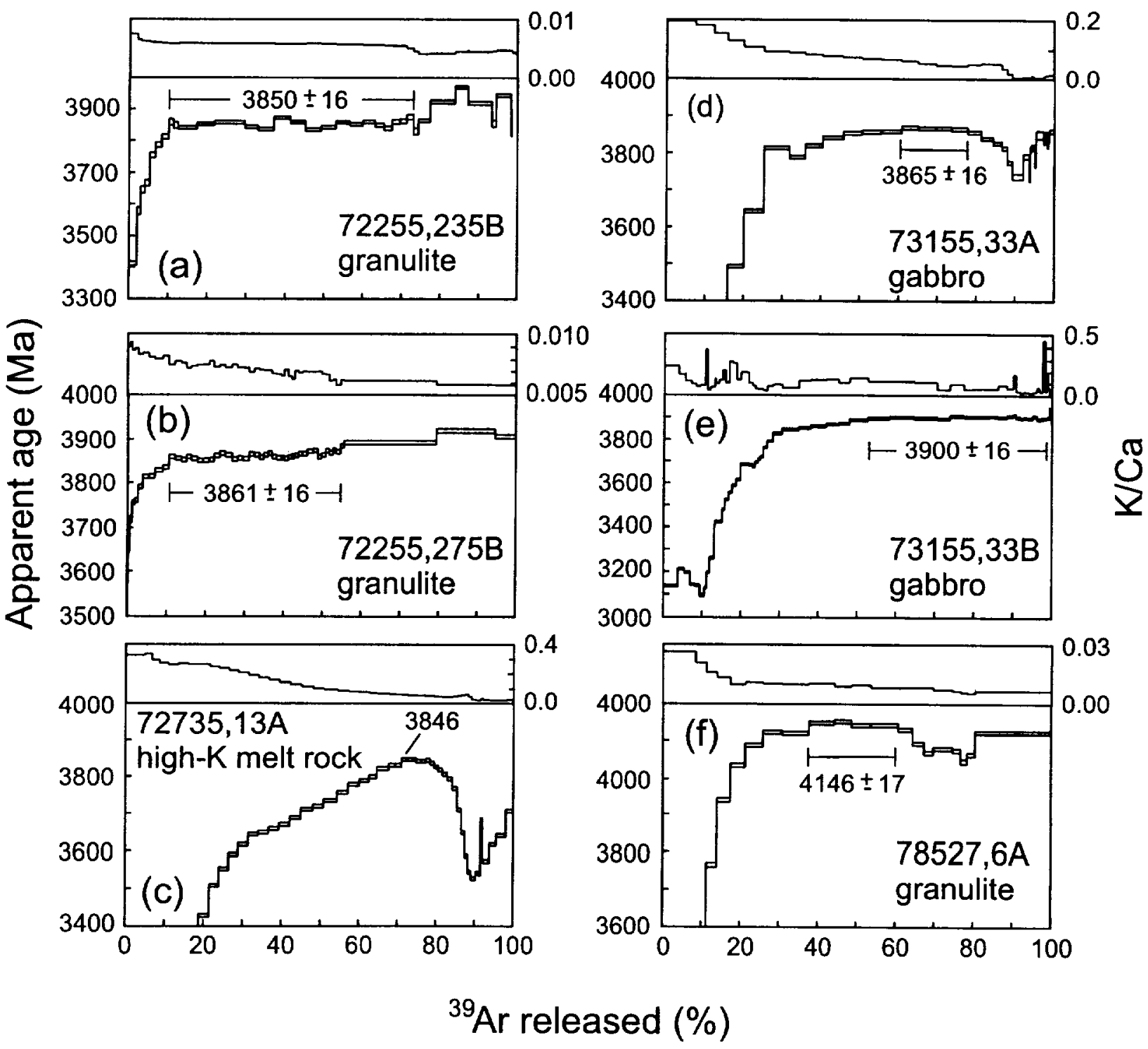

Figure 4. The ${ }^{41} \mathrm{Ar} \mathrm{r}^{34} \mathrm{Ar}$ age spectra, measured by laser incremental heating, of Apollo 17 granulites, gabbros, and a high-K melt. Explanation as in Figure 2. 
and indicates an age of $3835 \pm 16 \mathrm{Ma}$. The age spectrum shows effects of thermal Ar loss (low- $T$ increments) and of recoil (high$T$ increments). We interpret the plateau age as a cooling or crystallization age. Another, smaller fragment of this sample gave a similar age spectrum, but of poorer quality, with a plateau age of $3851 \pm 16 \mathrm{Ma}$.

Sample 72395,96A (poikilitic). This poikilitic melt rock has an intermediate- $T$ plateau at an age of $3893 \pm 16$ Ma represented by $36 \%$ of the ${ }^{39} \mathrm{Ar}$ released (Figure $2 \mathrm{a}$ ). The age spectrum shows minor effects of thermal reheating in the low- $T$ increments and the effects of ${ }^{34} \mathrm{Ar}$ recoil in both the low- $T$ and high- $T$ increments. The anomalous "spike" in the middle of the plateau is almost certainly due to an anomalous "Ar background, which happens rarely in the laser extraction system. The anomalous step has been excluded from the weighted mean age calculation, but if this increment is included the age is $3895 \pm 16 \mathrm{Ma}$.

Sample 72535,7A (poikilitic). The age spectrum of this poikilitic melt rock (shown as Figure 1 of Dalrymple and Ryder, [1996]) has a low- to intermediate- $T$ plateau including $31 \%$ of the ${ }^{34} \mathrm{Ar}$ released and indicates an age of $3887 \pm 16 \mathrm{Ma}$. Both the low- and high- $T$ increments show effects of recoil, and the low- $T$ increments show small thermal reheating effects. We interpret the plateau as representing a crystallization age.

Sample 72558,7A (poikilitic). The age spectrum of this poikilitic melt rock does not have a plateau, but instead rises to a maximum of $3869 \mathrm{Ma}$ at about $75 \%$ of the ${ }^{34} \mathrm{Ar}$ released (Figure 2b). The age spectrum shows severe effects of thermal Ar loss in the low- $T$ increments and ${ }^{34} \mathrm{Ar}$ recoil effects in the high- $T$ increments. We interpret this age spectrum as indicating a minimum age of $3869 \mathrm{Ma}$ for his sample.

Sample 72735,13A (high-K). The age spectrum for this high$\mathrm{K}$ melt rock (Figure $4 \mathrm{c}$ ) does not have a plateau but rises to a maximum of $3846 \mathrm{Ma}$ at about $70 \%{ }^{34} \mathrm{Ar}$ released. The sample shows the effects of substantial thermal Ar loss in the low- $T$ increments, and of recoil in the high- $T$ increments. We interpret this age spectrum as indicating a minimum age of $3846 \mathrm{Ma}$ for the sample.

Sample 73155,33A (gabbro). The age spectrum of this clast, which was enclosed within poikilitic melt, has a small high- $T$ plateau at $3865 \pm 16 \mathrm{Ma}$ that includes $17 \%$ of the ${ }^{19} \mathrm{Ar}$ released (Figure 4d). The sample also shows substantial effects of thermal Ar loss in the low- $T$ increments and of some ${ }^{39} \mathrm{Ar}$ recoil in the high- $T$ increments. We interpret the plateau as indicating a crystallization/cooling age.

Sample 73155,33B (gabbro). The age spectrum of this clast, which was enclosed within poikilitic melt, has a substantial high$T$ plateau at $3900 \pm 16 \mathrm{Ma}$ that includes $47 \%$ of the ${ }^{34} \mathrm{Ar}$ released (Figure 4e). It shows effects of thermal Ar loss in the low- $T$ increments, but no effects of ${ }^{34} \mathrm{Ar}$ recoil. We interpret the plateau as indicating a crystallization/cooling age.

Sample 73155,33E (poikilitic). The age spectrum of this melt rock fragment (Figure $2 \mathrm{c}$ ) has an intermediate- $T$ plateau at $3854 \pm 16 \mathrm{Ma}$ that includes $34 \%$ of the ${ }^{34} \mathrm{Ar}$ released. The age spectrum shows slight effects of thermal Ar loss in the low- $T$ increments and ${ }^{39} \mathrm{Ar}$ recoil effects in the high- $T$ increments. We interpret the plateau as indicating a crystallization/cooling age.

Sample 73155,34A (poikilitic). The age spectrum of this melt rock fragment (Figure 2d) has an equivocal intermediate- $T$ plateau at $3937 \pm 16 \mathrm{Ma}$. The age spectrum shows minor effects of thermal Ar loss in the low- $T$ increments and ${ }^{39}$ Ar recoil effects in the high- $T$ increments. We are unsure whether the "plateau" represents a crystallization age or a minimum age of $\sim 3944 \mathrm{Ma}$ (oldest increments). This fragment is of the same melt matrix as sample $73155,33 \mathrm{E}$, yet the age spectra of the two samples are quite different. We suspect that the age spectrum of this fragment $(73155,34 \mathrm{~A})$ is affected by older clasts

Sample 76315,150A (poikilitic). The age spectrum for this melt rock has a good intermediate- $T$ plateau at $3900 \pm 16$ Ma that includes $34 \%$ of the ${ }^{3 y} \mathrm{Ar}$ released (Figure $2 \mathrm{e}$ ). The sample shows effects of ${ }^{14} \mathrm{Ar}$ recoil but not of thermal Ar loss. We interpret the plateau as representing a crystallization age

Sample 77135,178A (poikilitic). The age spectrum for this melt rock does not have a plateau but rises to a maximum or 3743 $\mathrm{Ma}$ at about $75 \%$ of the ${ }^{\mathrm{Bg}} \mathrm{Ar}$ released (Figure $2 \mathrm{f}$ ). This sample has suffered substantial effects of thermal Ar loss, and we interpret the maximum in the age spectrum as a minimum age for the crystallization of the sample.

Sample 78527,6A (granulitic). The age spectrum for this granulite (Figure $4 \mathrm{f}$ ) has a small and equivocal intermediate- $T$ plateau at $4146 \pm 17 \mathrm{Ma}$. The sample shows effects of substantial thermal Ar loss in the low- $T$ increments along with ${ }^{34} \mathrm{Ar}$ recoil in the high- $T$ increments. We interpret this age spectrum as representing a minimum age of $4146 \mathrm{Ma}$ for the crystallization or cooling of the sample.

\section{Discussion}

Three of the poikilitic melt rocks we studied $(72395,96 \mathrm{~A}$, $72535,7 \mathrm{~A}$, and $76315,150 \mathrm{~A}$ ) have age spectra of similar shape, plateaus that fall within the narrow range of $3887-3900 \mathrm{Ma}$, and a weighted mean age of $3893 \pm 9 \mathrm{Ma}$. The melts come from both the North and South Massifs, and we infer their age to be the best age for the impact that formed the Serenitatis basin. Of these three melts, only 76315 has been previously dated. Turner and Cadogan [1975] obtained a relatively high-resolution age spectrum with a plateau at $3.92 \pm 0.03 \mathrm{Ga}$ that included $69 \%$ of the ${ }^{34} \mathrm{Ar}$ released. The sample, however, was $47 \mathrm{mg}$ in mass and it is unlikely that it was entirely free of contaminating clasts. Turner and Cadogan obtained identical plateau ages for samples of light $(3.91 \pm 0.04 \mathrm{Ga})$ and dark $(3.92 \pm 0.05 \mathrm{Ga})$ clasts from 76315 and tentatively associated these ages with the formation of Serenitatis. These results are not significantly different from our mean value of $3893 \mathrm{Ma}$ at the $95 \%$ level of confidence but are less precise.

Neither 72558,7A nor 77135,178A gave plateaus and it is obvious from their spectra that both have suffered substantial $\mathrm{Ar}$ loss (Figures $2 \mathrm{~b}$ and $2 \mathrm{f}$ ). The two samples have maximum ages of $3869 \mathrm{Ma}$ and $3743 \mathrm{Ma}$, respectively, which are consistent with our age for Serenitatis. Stettler et al. [1974, 1975] and Turner and Cadogan [1975] obtained several age spectra for 77135. All but one, however, gave spectra similar to ours (Figure 2f) indicative of substantial thermal Ar loss and also showing some ${ }^{34} \mathrm{Ar}$ recoil effects. The single exception gave a good plateau with an age of $3.84 \pm 0.03 \mathrm{Ga}$ [Stettler et al., 1975]. These results suggest that 77135 was affected by one or more local impact events well after the original formation of the poikilitic melt. At least one impact had to have occurred after $3.74 \mathrm{Ga}$ (Figure 2f) and another at $3.84 \mathrm{Ga}$. Whether this latter age records the original event that created the poikilitic melt in this rock or was a postformational impact that reset the ${ }^{40} \mathrm{Ar} /{ }^{39} \mathrm{Ar}$ system is not clear, but in view of our other (and older) results on the poikilitic melt rocks, the latter is the most straightforward explanation. Thus we do not interpret the age of $3.84 \mathrm{Ga}$ obtained by Stettler et al. [1975] as the age of the Serenitatis impact. 
Our results from samples from 73155 are more difficult to interpret. The poikilitic melt sample $73155,33 \mathrm{E}$ has a good plateau at $3854 \pm 16 \mathrm{Ma}$, whereas sample $73155,34 \mathrm{~A}$ has an equivocal "plateau" at $3937 \pm 16 \mathrm{Ma}$ (Figures $2 \mathrm{c}$ and 2d). The gabbro sample $73155,33 \mathrm{~A}$ (Figure 4d) has a small plateau at $3865 \pm 16 \mathrm{Ma}$, which is similar to the plateau age of melt $73155,33 \mathrm{E}$. The other gabbro, 73155,33B (Figure 4e), has a good high- $T$ plateau at $3900 \pm 16$. We are not sure that the two gabbro samples are free of melt because the melt invades the gabbro, and this may explain the dissimilarity in their age spectra. The age spectrum from 73155,33A, for example, shows effects of ${ }^{39} \mathrm{Ar}$ recoil in the high$T$ steps (Figure $4 \mathrm{~d}$ ), as is typical for fine-grained melt samples, whereas that of 73155,33B (Figure 4e) does not. We can interpret the results from 73155 but we do not believe that they provide unequivocal information about the age of Serenitatis. A likely explanation is that the rock was formed in the Serenitatis impact at 3890-3900 Ma (gabbro 33B) and was affected by a second thermal event at $3850-3860 \mathrm{Ma}$, which disturbed the $\mathrm{Ar}$ systems in melt rock 33E and gabbro 33A. The result from melt rock $34 \mathrm{~A}$ is then the result of contamination by one or more older and highly refractory clasts. A third thermal event more recent than about $3500 \mathrm{Ma}$ is required to explain the thermal Ar loss expressed in the low-T steps of 33A, 33B, and 33E.

Two of the five aphanitic melts studied from 72255 (72255,238 and 72255,255; Figures $3 \mathrm{a}$ and $3 \mathrm{c}$ ) and the two granulites enclosed in the aphanitic melt (Figures $4 a$ and $4 b$ ) have plateau ages that fall in the narrow range of 3850-3869 Ma and are not significantly different from each other at the $95 \%$ level of confidence. The weighted mean of these four ages (3862 \pm 8 $\mathrm{Ma}$ ) is, however, significantly different from the weighted mean age of $3893 \pm 9 \mathrm{Ma}$ found for the poikilitic (Serenitatis) melts. A third aphanitic melt $(72255,248$. Figure $3 \mathrm{~b})$ has a plateau age of $3883 \pm 16 \mathrm{Ma}$, which is similar to the age of the Serenitatis poikilitic melts, while aphanite 72255,282 has a plateau age of $3951 \pm 17 \mathrm{Ma}$, which exceeds by far the age of any of the Serenitatis melts (Figure 3e). The age spectrum of the fifth aphanite (72255,256; Figure 3d) indicates that it, or its clasts, formed prior to $3894 \mathrm{Ma}$. The poikilitic melt enclosed within the aphanitic melt has an age spectrum plateau that indicates a crystallization age of $3835 \pm 16 \mathrm{Ma}$. This fixes an upper limit for the accretion of 72255 , because that age cannot exceed the age of the poikilitic melt inclusion. Since this poikilitic melt differs in composition from the Serenitatis poikilitic melts, and therefore was created in a different impact melting event, the age of $3835 \mathrm{Ma}$ is not inconsistent with our age for Serenitatis.

There has been only one previous ${ }^{40} \mathrm{Ar}{ }^{39} \mathrm{Ar}$ age spectrum measured for 72255 aphanitic melt. Leich et al. [1975] obtained what they considered to be a reliable three-step intermediate- $T$ ${ }^{40} \mathrm{Ar}{ }^{3 y} \mathrm{Ar}$ plateau age of $3.93 \pm 0.03 \mathrm{Ga}$ on an aphanite from 72255. The age spectrum, however, may have been compromised by the plagioclase clasts, which have demonstrably older apparent ages [Schaeffer et al., 1982a, b]. Schaeffer and his colleagues used laser spot melting techniques on a thin section of 72255 , targeting mainly plagioclase and felsite clasts, whose ages would provide upper limits for the assembling impact. The felsite gave ages of about $3.85 \mathrm{Ga}$, whereas the plagioclase clasts had apparent ages of $-3.91 \mathrm{Ga}$. These spot melting ages, however, are total fusion ages and there is no way to evaluate the effects of postcrystallization $\mathrm{Ar}$ loss or of ${ }^{39} \mathrm{Ar}$ recoil. Since completely undisturbed lunar samples are essentially nonexistent, the laser spot melting ages of Schaeffer et al. [1982a, b] should be interpreted with caution, but they are consistent with our upper limit of $3835 \pm 16 \mathrm{Ma}$ for the accretion event.
It is clear from our results on 72255 that the aphanites have a complex chronological history. One interpretation of the age data is that the aphanites we studied are inclusions that differ in age, a possibility that is not precluded by the petrographic or chemical data. According to this interpretation, some of the aphanites in 72255 are as old as or older than the Serenitatis poikilitic melts, while most formed $\sim 3862 \mathrm{Ma}$, at which time the $\mathrm{Ar}$ isotopic systems in the granulites were completely reset. Another interpretation is that all of the aphanites formed $\sim 3862 \mathrm{Ma}$ but the age spectra of some are affected by older clasts. Regardless of the age(s) of the aphanites, 72255 was finally assembled by an impact event more recent than $3835 \mathrm{Ma}$ and since the poikilitic melt shows substantial effects of postcrystallization $\mathrm{Ar}$ loss in the low- $T$ steps, 72255 must have been moderately affected by one or more postaccretion impacts that did not completely reset the Ar isotopic system.

Another interpretation of the results for 72255 is that the aphanites are the age of Serenitatis or older ( $3894 \mathrm{Ma})$ and their Ar isotopic systems have been completely reset at different times by different postcrystallization impact or heating events. Such events would require multiple high-temperature events for long periods of time, each event resetting the Ar system in some parts of the rock but leaving other parts unchanged; this seems unlikely.

There is minimal chronological information in the age spectrum of high-K melt 72735,13A (Figure 4c). This melt formed in an impact event that occurred at or before $3846 \mathrm{Ma}$ and was affected quite significantly by at least one relatively recent impact/heating event. There is nothing in the ${ }^{40} \mathrm{Ar} /{ }^{31} \mathrm{Ar}$ age information itself that precludes this melt from being a Serenitatis melt, but its composition, which is significantly different from the Serenitatis poikilitic melts, suggests that it was formed in a different, i.e., non-Serenitatis, impact.

The noritic granulite $78527,6 \mathrm{~A}$ has a ${ }^{40} \mathrm{Ar} /{ }^{34} \mathrm{Ar}$ plateau age of $4146 \pm 17 \mathrm{Ma}$ and apparently was formed at least $250 \mathrm{~m}$.y. prior to the Serenitatis impact. It has been affected by one or more post-Serenitatis heating/impact events because its age spectrum shows the effects of thermal Ar loss in the low- $T$ steps.

\section{Age of Serenitatis and Lunar Basin Chronology}

Age estimates of the Serenitatis Basin based on different methods have varied widely. Stuart-Alexander and Howard [1970], using geomorphic criteria and the overall degree of destruction, concluded that Serenitatis was one of the older of the nearside basins. Early studies of the densities of large craters on basin ejecta blankets also concluded that Serenitatis was relatively old [e.g., Baldwin, 1969; Hartmann and Wood, 1971] (summarized by Dalrymple [1991]), whereas more recent studies of crater densities have tended to assign a more recent relative age to Serenitatis [e.g., Wilhelms, 1984]. Baldwin [1987a, b] concluded from crater densities and from the presumed relaxation of basin rim heights due to hot "creep" that Serenitatis was relatively young, and on the basis of a radiometric age of $3.85 \mathrm{Ga}$ for the Imbrium Basin, estimated ages for Serenitatis of $4.09 \mathrm{Ga}$ (crater density) and $4.14 \mathrm{Ga}$ (rim heights).

Age estimates for the Serenitatis Basin based on radiometric data, much of which is from other than melt rocks, have also varied. Huneke et al. [1973] and Tumer et al. [1973] determined nearly identical ${ }^{40} \mathrm{Ar} / \mathrm{*}$ Ar plateau ages of $3.91 \pm 0.04 \mathrm{Ga}$ and 3.92 $\pm 0.05 \mathrm{Ga}$ for Apollo 17 sample 76055 , which they thought was excavated by and recorded the time of formation of the Serenitatis basin. On the basis of U-Th-Pb systematics and following the 
relative age sequence suggested by Stuart-Alexander and Howard, Nunes et al. [1974] assigned a tentative age of $\sim 4.45 \mathrm{Ga}$ to the formation of the Serenitatis basin. Husain and Schaeffer [1975] concluded that troctolite 76535 , for which they measured an ${ }^{41} \mathrm{Ar}{ }^{34} \mathrm{Ar}$ closure age of $4.19 \pm 0.02 \mathrm{Ga}$, was most likely first excavated by the Serenitatis event. Cadogan and Turner [1976] measured ${ }^{40} \mathrm{Ar} /{ }^{34} \mathrm{Ar}$ ages ranging from $3.86 \pm 0.04 \mathrm{Ga}$ to $4.04 \pm$ $0.05 \mathrm{Ga}$ on 15 samples of clasts, mineral concentrates, and matrix from the Apollo 17 Station 6 boulder and concluded that the impact event that formed these samples, probably the Serenitatis impact, occurred $3.90 \pm 0.04 \mathrm{Ga}$. In two early syntheses, Turner and Cadogan [1975] and Turner [1977] concluded that the preponderance of ${ }^{411} \mathrm{Ar} /{ }^{34} \mathrm{Ar}$ ages for "strongly annealed" and chemically similar noritic samples suggested an age of $3.92 \mathrm{Ga}$ for the Serenitatis event. Stettler et al. [1978] measured an ${ }^{40} \mathrm{Ar} /{ }^{34} \mathrm{Ar}$ age of $3.98 \mathrm{Ga}$ for plagioclase from a brecciated noritic igneous rock from the Apollo 17 Station 7 boulder, which they correlated with the excavation and impregnation of the breccia with vein material inferred to have formed during the Serenitatis event. The ${ }^{40} \mathrm{Ar}{ }^{34} \mathrm{Ar}$ ages of $3.88 \pm 0.02 \mathrm{Ga}$ and $3.87 \pm 0.01 \mathrm{Ga}$ on aphanitic matrix from a light gray breccia/melt bomb (73255) and on a felsite (73215), respectively, led Jessberger et al. [1978] to conclude that Serenitatis was $3.88 \mathrm{Ga}$. Wilhelms [1987] evaluated the extant age data and concluded that the age of the Serenitatis basin was 3.86-3.87 Ga, but his conclusion was based on the agreement between the youngest ${ }^{40} \mathrm{Ar} /{ }^{34} \mathrm{Ar}$ ages from sample 73255, an aphanite sample whose provenance is uncertain [Spudis, 1978], and an ${ }^{40} \mathrm{Ar} /{ }^{79} \mathrm{Ar}$ plateau age from a single-crystal plagioclase clast from sample 72435 [Huneke, 1978], a poikilitic sample from boulder 3, Station 2. In a recent evaluation of published isotopic data, Nyquist and Shih [1992] concluded that Serenitatis, Crisium, and Nectaris are only slightly older than Imbrium $(-3.85 \mathrm{Ga})$ and probably all formed within a period of about $80 \mathrm{Ma}$.

We have plotted all extant ages determined from plateaus in ${ }^{411}$ Ar ${ }^{37} \mathrm{Ar}$ age spectra for poikilitic melt rocks of "Serenitatis" composition in Figure 5. The data from the literature are varied in quality. Many are from questionable plateaus and the studies prior to ours utilized large samples in which clasts were almost certainly present. The arithmetic mean age of these published data is $3892 \pm 66 \mathrm{Ma}(n=14)$. If all of our data are included, the arithmetic mean is $3893 \pm 62 \mathrm{Ma}(n=19)$. The weighted mean of all of the ages, which takes into account the varied quality of the individual data, is $3894 \pm 6 \mathrm{Ma}(n=19)$. (For this calculation we assigned a $2 \sigma$ error of $50 \mathrm{Ma}$ to the two ages for which errors were not reported.) These results are identical, except in preci-

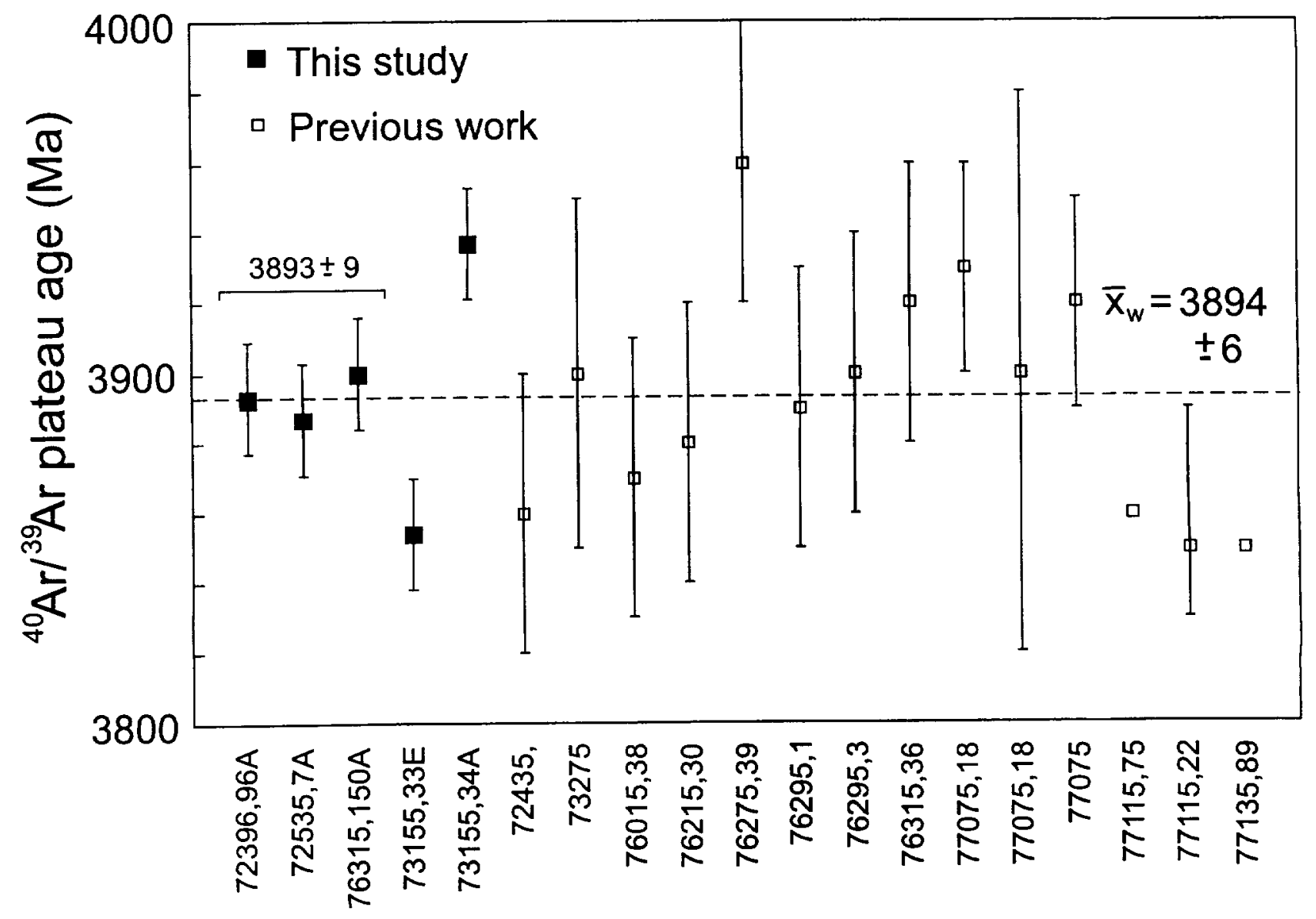

Figure 5. The ${ }^{40} \mathrm{Ar}{ }^{34} \mathrm{Ar}$ age spectrum plateau ages for Apollo 17 poikilitic melt rocks. All of the melt samples have similar compositions and are generally regarded as representing the Serenitatis impact melt sheet. Vertical bars indicate estimated errors at the $2 \sigma$ level. The weighted mean of all data is indicated by the dashed line; error is $2 \sigma_{\text {text. }}$. Published data are from Cadogan and Turner [1976], Huneke et al. [1977], Stettler et al. [1974, 1975, 1978], and Turner and Cadogan [1975]. 
sion, to the weighted mean age of $3893 \pm 9 \mathrm{Ma}$ for the three Serenitatis melts that we dated and that we infer most reliably record the age of the Serenitatis event.

Despite the fact that it makes little difference in the numerical result, we prefer the age for the Serenitatis impact based on our three melt rock samples over mean values that use the older data for several reasons. Our result is based on greatly improved methods that (1) utilize very small samples and thus allow us to avoid, as much as possible, the effects of clasts and (2) result in very detailed and precise age spectra that allow us to be more critical in selecting plateaus. Thus, we conclude that the Serenitatis basin was formed $3893 \pm 9 \mathrm{Ma}$.

Our new data, for the first time, allow a quantitative distinction between the ages of the Imbrium and Serenitatis basins based on radiometric age data. Previous radiometric ages for these two important events have been too imprecise to preclude the possibility that these two impacts were of similar age. In our previous study of Apollo 15 melt rocks [Dalrymple and Ryder, 1993] we found that six melt rocks, representing at least three and perhaps four distinct impact events, had similar ${ }^{40} \mathrm{Ar} /{ }^{34} \mathrm{Ar}$ plateau ages with a mean of $3867 \pm 4 \mathrm{Ma}$. A seventh Apollo 15 melt, also with a distinct composition, gave a plateau age of $3836 \pm 11 \mathrm{Ma}$. From these data we concluded that the Imbrium impact was no older than $3870 \mathrm{Ma}$ and probably no older than $3836 \mathrm{Ma}$. On the basis of the geology of the Apollo 15 landing site it was expected that Serenitatis melts, in addition to Imbrium melts, might be present in the Apollo 15 collection [Swann and al., 1972]. We speculated that precise age data for the Apollo 17 poikilitic (Serenitatis) melts would show which, if any, of our Apollo 15 melt rock ages represented the Serenitatis impact [Dalrymple and Ryder, 1991]. Our new age of $3893 \pm 9$ Ma for Serenitatis indicates, however, that the Serenitatis impact is distinctly older than any of the Apollo 15 melts we analyzed. In addition, none of the Apollo 15 melts we studied are identical in chemical composition to the Apollo 17 Serenitatis melts [Dalrymple and Ryder, 1993], which is consistent with the age results. Our results also show that Serenitatis is measurably older than Imbrium even if Imbrium is as old as our maximum estimate of $3870 \mathrm{Ma}$.

The significance of this precise age for Serenitatis depends on its relative age with respect to other impact basins, for which the evidence is poor. If Serenitatis is one of the older basins, then much of the visible nearside landscape formed in 55-60 m.y. or less. If Serenitatis is relatively young, then the history of lunar basin formation might have extended over a much longer period of time. This important question cannot be answered until either there is better evidence for the relative/stratigraphic age of Serenitatis or precise radiometric ages for more of the lunar basins.

Nectaris is the only other nearside basin whose age can be reasonably inferred from radiometric data $(\sim 3.89-3.92$ Ga [Nyquist and Shih, 1992; Ryder, 1990; Wilhelms, 1987]), but even so such an inference is much less sound than for Imbrium or Serenitatis. Our age for Serenitatis is consistent with this inferred age range and with stratigraphic evidence indicating that Nectaris is older than Serenitatis. Orientale, an undated basin located on the western limb of the Moon with a probable age of 3.81-3.83 Ga, is the youngest of the basins for which an age can be reasonably inferred. There are several undated basins, including Crisium, Humorum, and Humboldtianum, that are intermediate in age between Orientale and Nectaris [Wilhelms, 1987]. Some of the Apollo 15 melts for which we obtained precise ages [Dalrymple and Ryder, 1991, 1993] may be products of the events that formed these intermediate basins, but there is no way at present to associate individual ages with particular basins.
Swindle et al. [1991] concluded that most of the melt rocks from the Luna 20 collection, which was expected to sample Crisium material, either is of local origin or is chemically identical to the Serenitatis poikilitic melts. They tentatively identified a single melt with a distinctive composition and an age of $3.895 \pm$ $0.017 \mathrm{Ga}$ as a product of the Crisium impact. If this age is correct, then Crisium and Serenitatis are very similar in age.

On stratigraphic grounds there are some basins that are older than Serenitatis and Nectaris, so basin formation clearly began prior to 3.90-3.92 $\mathrm{Ga}$, but how much earlier is not apparent from the extant radiometric data. As was discussed above, rheological and crater-counting methods [Baldwin, 1987a, b] have yielded ages of $4.1 \mathrm{Ga}$ and older for Serenitatis and pre-Serenitatis basins, but such ages are model dependent, highly speculative, and contradicted by radiometric data; they also are clearly wrong, for it is virtually impossible to derive a geological scenario for making the Apollo 17 poikilitic melts in a post-Serenitatis event.

So far, there is still no tangible evidence for a significant number of basin-forming impacts substantially older than $3.9 \mathrm{Ga}$. The older ages of granulites such as 78527 reflect ancient events that might be the accretionary impacting of the Moon prior to 4.4 Ga followed by prolonged burial of the resulting breccias in a hot crust. Only further radiometric dating of carefully selected melt rocks will provide a quantitative basin chronology and answer the important question of when lunar basin formation began. We hope to begin analyses of Apollo 16 melt rocks soon in order to provide a more definitive and precise age for the events represented by the rocks, one of which might be the Nectaris impact, and to continue our search, so far unfruitful, for impact melts that record pre-3.9 $\mathrm{Ga}$ basin-forming impacts.

Acknowledgments. We thank the staffs of the Los Alamos National Laboratory Omega West Reactor, the University of Michigan Ford Reactor, and the Brookhaven National Laboratory High Flux Beam Reactor (HFBR) for irradiating the samples, James Saburomaru and Marvin Lanphere of the U.S. Geological Survey for their assistance with the "Ar/"Ar measurements; Rene Martinez and David Mittelfehldt of Lockheed Corporation at the Johnson Space Center for their assistance with the neutron activation analyses; and Linda Watts of the Lockheed Corporation at the Johnson Space Center for her assistance with sample processing. We also thank Donald Bogard and Bernard Hawke for their thoughtful and constructive reviews of the manuscript. Chris Hall generously agreed to irradiate some of our sample along with his own in the Ford Reactor when the Omega West Reactor and HFBR were unavailable. This work was done with support from NASA's Planetary Materials and Geochemistry Program. The Lunar and Planetary Institute is operated by the Universities Space Research Association under contract NASW-4066 with the National Aeronautics and Space Administration. LPI contribution 896 .

\section{References}

Baldwin, R. B., Ancient giant craters and the age of the lunar surface, Astron. J., 74, 570-571, 1969.

Baldwin, R. B., Was there a "terminal lunar cataclysm" $3.9-4.0 \times 10^{9}$ years ago?, Icarus, 23, 157-166, 1974.

Baldwin, R. B., On the origin of the planetesimals that produced the multi-ring basins, Proc. Lunar Planet. Sci. Conf., 12A, 19-28, 1981.

Baldwin, R. B., On the relative and absolute ages of seven lunar front face basins, I, From viscosity arguments, Icarus, 71, 1-18, 1987a.

Baldwin, R. B., On the relative and absolute ages of seven lunar front face basins, II, From crater counts, Icarus, 7I, 19-29, $1987 \mathrm{~b}$.

Blanchard, D. P., L. A. Haskin, J. W. Jacobs, J. C. Brannon, and R. L. Korotev, Major and trace element chemistry of Boulder 1 at Station 2. Apollo 17, Moon, 14, 359-371, 1975. 
Brown, R. W., A sample fusion technique for whole rock analysis with the electron microprobe, Geochim. Cosmochim. Acta, 4I, 435-438, 1977.

Cadogan, P. H., and G. Turner, The chronology of the Apollo 17 Station 6 boulder, Proc. Lunar Sci. Conf., 7 , 2267-2285, 1976.

Cushing, J. A., G. J. Taylor, M. D. Norman, and K. Keil, The granulitic impactite suite: Impact melts and metamorphic breccias of the early lunar crust, Earth Planet. Sci. Lett., in press, 1996.

Dalrymple, G. B., The GLM continuous laser system for ${ }^{40} \mathrm{Ar} /$ " Ar dating: Description and performance characteristics, in New Frontiers in Stable Isotopic Research, edited by W. C. Shanks, III, and R. E. Criss, U.S. Geol. Survey Bull., 1890, 89-96, 1989.

Dalrymple, G. B., The Age of the Earth, 474 pp., Stanford Univ. Press, Stanford, Calif., 1991.

Dalrymple, G. B., and W. A. Duffield, High precision " ${ }^{40}$ A $f^{30}$ Ar dating of Oligocene rhyolites from the Mogollon-Datil volcanic field using a continuous laser system, Geophys. Res. Lett., IS, 463-466, 1988.

Dalrymple, G. B., and G. Ryder, ${ }^{40} \mathrm{Ar}{ }^{37} \mathrm{Ar}$ laser step heating ages of some Apollo 15 impact melt rocks, Lunar Planet. Sci., XXIX, 273-274, 1991.

Dalrymple, G. B., and G. Ryder, ${ }^{\text {* }}$ Ar/" Ar age spectra of Apollo 15 impact melt rocks by laser step-heating and their bearing on the history of lunar basin formation, $J$. Geophys. Res., 98, 13,085-13,095, 1993.

Dalrymple, G. B., and G. Ryder, " $\mathrm{Ar} /{ }^{37} \mathrm{Ar}$ laser step heating ages of some Apollo 17 melt rocks and the age of the Serenitatis impact, Lunar Planet. Sci., XXVII, 285-286, 1996.

Deuce, M. R., R. A. F. Grieve, and A. G. Plant, Apollo 17 grey breccias and crustal composition in the Serenitatis basin region, Proc. Lunar Sci. Conf., 7th, 1821-1832, 1976.

Dymek, R. F., A. L. Albee, and A. A. Chodos, Petrology and origin of Boulders 2 and 3, Apollo 17, Station 2, Proc. Lunar Sci. Conf., 7th, 2335-2378, 1976.

Eichorn, G., J. J. McGee, O. B. James, and O. A. Schaeffer, Consortium breccia 73255: Laser ${ }^{39} \mathrm{Ar}-{ }^{40} \mathrm{Ar}$ dating of aphanite samples, Proc. Lunar, Planet. Sci. Conf., 1Oth, 763-788, 1979.

Floran, R. J., R. A. F. Grieve, W. C. Phinney, J. L. Warner, C. H. Simonds, D. P. Blanchard, and M. R. Dence, Manicouagan impact melt, Quebec, 1. Stratigraphy, petrology, and chemistry, J. Geophys. Res., 83, 2737-2759, 1978.

Hall, C. M., Calculation of expected thermal gradients in laser ${ }^{40} \mathrm{Ar} /{ }^{\prime \prime} \mathrm{Ar}$ step-heating experiments (abstract), Eos Trans. AGU, 7I, 653, 1990.

Hartmann, W. K., Lunar "cataclysm": A misconception?, lcarus, 24, $181-187,1975$.

Hartmann, W. K., Dropping stones in magma oceans: Effects of early lunar cratering, Geochim. Cosmochim. Acta, 12, suppl., 155-171, 1980.

Hartmann, W. K., and C. A. Wood, Moon: Origin and evolution of multi-ring basins, Moon, 3, 3-78, 1971.

Hohenberg, C. M., K. Marti, F. A. Podosek, R. C. Reedy, and J. R. Shirck, Comparisons between observed and predicted cosmogenic noble gases in lunar samples, Proc. Lunar Planet. Sci. Conf., 9th, 2311-2344, 1978

Huneke, J. C., ${ }^{40} \mathrm{Ar}-{ }^{39} \mathrm{Ar}$ microanalysis of single glass balls and 72435 breccia clasts, Proc. Lunar Planet. Sci. Conf., 9th, 2345-2362, 1978.

Huneke, J. C., and S. P. Smith, The realities of recoil: ${ }^{39} \mathrm{Ar}$ recoil out of small grains and anomalous age patterns in ${ }^{39} \mathrm{Ar}-{ }^{40} \mathrm{Ar}$ dating, Proc. Lunar Sci. Conf., 7th, 1987-2008, 1976.

Huneke, J. C., E. K. Jessberger, F. A. Podosek, and G. J. Wasserburg, ${ }^{40} \mathrm{Ar} /$ "Ar measurements in Apollo 16 and 17 samples and the chronology of metamorphic and volcanic activity in the Taurus-Littrow region, Proc. Lunar Sci. Conf., 4th, 1725-1756, 1973.

Huneke, J. C., F. Radicati di Brozolo, and G. J. Wasserburg, ${ }^{40} \mathrm{Ar}-{ }^{39} \mathrm{Ar}$ measurements on lunar highlands rocks with primitive ${ }^{87} \mathrm{Rb} /{ }^{86} \mathrm{Rb}$, Lunar Planet. Sci., XVIII, 481-483, 1977.

Husain, L., and O. A. Schaeffer, Lunar evolution: The first 600 million years, Geophys. Res. Lett., 2, 29-32, 1975.

James, O. B., J. W. Hedenquist, D. P. Blanchard, J. R. Budahu, and W. Compston, Consortium breccia 73255: Petrology, major- and trace- element chemistry, and $\mathrm{Rb}-\mathrm{Sr}$ systematics of aphanitic lithologies, Proc. Lunar Planes. Sci. Conf., 9th, 789-819, 1978.

Jessberger, E. K., T. Staudacher, B. Dominik, and T. Kirsten, Argonargon ages of aphanite samples from consortium breccia 73255 , Proc. Lunar Planet. Sci. Conf., 9th, 841-854, 1978.

Lanphere, M. A., G. B. Dalrymple, R. J. Fleck, and M. S. Pringle, Intercalibration of mineral standards for $\mathrm{K}-\mathrm{Ar}$ and ${ }^{40} \mathrm{Ar} / \mathrm{Ar}$ age measurements (abstract), Eos Trans. AGU, 71, 1658, 1990.

Laul, J. C., and R. A. Schmitt, Chemical composition of Apollo 17 samples: Boulder breccias (2), rake breccias (8) and others, Lunar Sci., VI, 489-491, 1975.

Leich, D., S. B. Kahl, A. R. Kirschbaum, S. Niemeyer, and D. Phinney, Rare gas constraints on the history of Boulder 1, Station 2, Apollo 17, Moon, 14, 407-444, 1975.

Lindstrom, M. M., U. B. Marvin, and D. W. Mittlefehldt, Apollo $15 \mathrm{Mg}$ and Fe-norites: A redefinition of the $\mathrm{Mg}$-suite differentiation trends, Proc. Lunar Planet. Sci. Conf., 19th, 245-254, 1989.

Marvin, U. B., The Boulder, Moon, 14, 31.5-326, 1975.

Meyer, C., Catalog of Apollo 17 rocks, vol. 4, N. Massif, 644 pp., NASA Johnson Space Cent., Houston, Tex., 1994.

Müller, H. W., T. Pleininger, O. B. James, , and O. A. Schaeffer, Laser probe ${ }^{40} \mathrm{Ar} /{ }^{\prime \prime} \mathrm{Ar}$ dating of materials from consortium breccia 73215 , Proc. Lunar Planet. Sci. Conf., 8th, 2551-2565, 1977.

Murali, A. V., M.-S. Ma, J. C. Laul, and R. A. Schmitt, Chemical composition of breccias, feldspathic basalt and anorthosites from Apollo $15(15308,15359,15382$, and 15362) Apollo 16 (60618 and 65785), Apollo $17(72434,72536,72559,72735,72738,78526$, and 78527) and Luna 20 (22012 and 22013), Lunar Planet. Sci., XVIII, 700-702, 1977.

NASA, Apollo 17 Preliminary Science Report, NASA Spec. Publ., SP. 330, 1973.

Nehru, C. E., R. D. Warner, K. Keil, and G. J. Taylor, Metamorphism of brecciated ANT rocks: Anorthositic troctolite 72559 and norite 78527, Proc. Lunar Planet. Sci. Conf., 9, 773-788, 1978.

Neukum, G., Lunar cratering, Philos. Trans. R. Soc. London, Ser. A , $285,267-272,1977$.

Nunes, P. D., M. Tatsumoto, and D. M. Unruh, U-Th-Pb systematics of some Apollo 17 lunar samples and implications for a lunar basin excavation chronology, Proc. Lunar Sci. Conf., 5, 1487-1514, 1974.

Nyquist, L. E., and C.-Y. Shih, The isotopic record of lunar volcanism, Geochim. Cosmochim. Acta, 56, 2213-2234, 1992.

Palme, H., et al., New data on lunar samples and achondrites and a comparison of the least fractionated samples from the Earth, the Moon, and the eucrite parent body, Proc. Lunar Planet. Sci. Conf., 9 th, 25. 57,1978

Ryder, G., Lunar samples, lunar accretion and the early bombardment of the Moon, Eos Trans. AGU, 71, 313, 322-323, 1990.

Ryder, G., A distinct poikilitic impact melt rock from the Apollo 17 landing site that is not from the Serenitatis melt sheet, Meteoritics, $27,284,1992 a$.

Ryder, G., Lunar highlands totality from bits and pieces: A whole-rockgeochemistry-free characterization of an evolved hypabyssal igneous gabbro schlieren from the Apollo 17 landing site, Lunar Planet. Sci. XXIII, 1195-1196, 1992b.

Ryder, G., Catalog of Apollo 17 rocks, vol. 1. Stations 2 and 3 (S. Massiff), 411 pp., NASA, Johnson Space Cent., Houston, Tex., 1993.

Ryder, G., Relationships among impact melt samples from the TaurusLittrow massifs, Apollo 17 landing site, Lunar Planet. Sci., XXVII, 1121-1122, 1996.

Ryder, G., D. B. Stoeser, U. B. Marvin, J. F. Bower, and J. A. Wood, Boulder 1, Station 2, Apollo 17: Petrology and petrogenesis, Moon, 14, 327-357, 1975

Schaeffer, O. A., R. Warasila, and T. C. Labotka, Ages of Serenitatis breccias, in Workshop on Lunar Breccias and Soils and Their Meteoritic Analogs, edited by G. J. Taylor and L. L. Wilkening, pp. 123125, Lunar and Planet. Inst., Houston, Texas, 1982a.

Schaeffer, O. A., R. Warasila, and T. C. Labotka, Ages of Serenitatis breccias, Lunar Planet. Sci., XIII, 685-686, $1982 \mathrm{~b}$. 
Spudis, P. D., Composition and origin of the Apennine Bench Formation, Proc. Lunar Planet. Sci. Conf., 9th, 3379-3394, 1978.

Spudis, P. D., and G. Ryder, Apollo 17 impact melts and their relation to the Serenitatis basin, Proc. Lunar Planet. Sci. Conf., I2A, 133-148, 1981 .

Staudacher, T., E. K. Jessberger, I. Flohs, and T. Kirsten, ${ }^{~} \mathrm{Ar} /{ }^{30} \mathrm{Ar}$ age systematics of consortium breccia 73255, Proc. Lunar Planet. Sci. Conf., 10th, 745-762, 1979.

Steiger, R. H., and E. Jäger, Subcommission on geochronology: Convention on the use of decay constants in geo- and cosmochronology, Earth Planet. Sci. Lett., 36, 359-362, 1977.

Stettler, A., P. Eberhardt, J. Geiss, and N. Grögler, ${ }^{~} \mathrm{Ar} /{ }^{\prime 10} \mathrm{Ar}$ ages of samples from the Apollo 17 Station 7 boulder and implications for its formation, Earth Planet. Sci. Lett., 23, 453-461, 1974.

Stettler, A., P. Eberhardt, J. Geiss, N. Grögler, and S. Guggisberg, Age sequence in the Apollo 17 Station 6 boulder, Lunar Sci., VI, 771773, 1975.

Stettler, A., P. Eberhardt, J. Geiss, N. Grögler, and S. Guggisberg, Chronology of the Apollo 17 Station 7 boulder and the South Serenitatis impact, Lunar Sci., IX, 1113-1115, 1978.

Stuart-Alexander, D. E., and K. A. Howard, Lunar maria and circular basins--A review, Jcarus, 12, 440-456, 1970.

Swann, G. A., et al., Preliminary geologic investigation of the Apollo 15 landing site, Apollo 15 preliminary science report. NASA Spec. Publ., 289, 1-112, 1972.

Swindle, T. D., P. D. Spudis, G. J. Taylor, R. I. Korotev, R. H. Nichols Jr., and C. T. Olinger, Searching for Crisium basin ejecta: Chemistry and ages of Luna 20 impact melts, Proc. Lunar Planet. Sci. Conf., 21st, 167-181, 1991.

Taylor, J. R., An Introduction to Error Analysis, 270 pp., Univ. Sci. Books, Mill Valley, Calif., 1982

Tera, F., D. A. Papanastassiou, and G. J. Wasserburg, Isotopic evidence for a terminal lunar cataclysm, Earth Planet. Sci. Lett., 22, 1-21, 1974.

Turner, G., Potassium-argon chronology of the Moon, Phys. Chem. Earth, 10, 145-195, 1977.

Turner, G., and P. H. Cadogan, Possible effects of ${ }^{39} \mathrm{Ar}$ recoil in ${ }^{40} \mathrm{Ar}$ ${ }^{39}$ Ar dating, Proc. Lunar Sci. Conf., 5th, 1601-1615, 1974.
Tumer, G., and P. H. Cadogan, The history of lunar bombardment inferred from ${ }^{40} \mathrm{Ar}-{ }^{39} \mathrm{Ar}$ dating of highland rocks, Proc. Lunar Sci. Conf., 6th, 1509-1538, 1975.

Tumer, G., P. H. Cadogan, and C. J. Yonge, Argon selenochronology, Proc. Lunar Sci. Conf., 4th, 1889-1914, 1973.

Wamer, J. L., C. N. Simonds, and W. C. Phinney, Apollo 17, Station 6 boulder sample 76255: Absolute petrology of breccia matrix and igneous clasts, Proc. Lunar Sci. Conf., 7th, 2233-2250, 1976.

Warner, R. D., G. J. Taylor, and K. Keil, Petrology of crystalline matrix breccias from Apollo 17 rake samples, Proc. Lunar Sci. Conf., 8th, 1987-2006, 1977.

Warren, P. H., G. J. Taylor, K. Keil, G. W. Kallemeyn, P. S. Rosener, and J. T. Wasson, Sixth foray for pristine non-mare rocks and an assessment of the diversity of lunar anorthosites, Proc. Lunar Planet. Sci. Conf., 13th, Part 2, J. Geophys. Res., 88, suppl., A615-A630, 1983.

Wilhelms, D. E, Moon, in The Geology of the Terrestrial Planets, edited by M. H. Carr, NASA Spec. Publ., SP-469, 107-205, 1984.

Wilhelms, D. E., The geologic history of the moon, U.S. Geol. Survey Prof. Pap., I348, 302 pp., 1987.

Winzer, S. R., D. F. Nava, P. J. Schuhmann, R. K. L. Lum, S. Schuhmann, M. M. Lindstrom, D. J. Lindstrom, and J. A. Philpotts, The Apollo 17 "melt sheet": Chemistry, age and Rb/Sr systematics, Earth Planet. Sci. Lett., 33, 389-400, 1977.

Wolfe, E. W., N. G. Bailey, B. K. Lucchitta, W. R. Muehlberger, D. H. Scott, R. L. Sutton, and H. G. Wilshire, The geologic investigation of the Taurus-Littrow Valley: Apollo 17 landing site, U.S. Geol. Survey Prof. Pap. 1080, 280 pp., 1981.

Wood, J. A., The nature and origin of boulder 1, station 2, Apollo 17, Moon, 14, 505-517, 1975.

G. B. Dalrymple, College of Oceanic and Atmospheric Sciences, Oregon State University, Corvallis, OR 97331-5503. (e-mail: gbd@oce.orst.edu)

G. Ryder, Lunar and Planetary Institute, 3600 Bay Area Boulevard, Houston, TX 77058-1113. (e-mail: zryder@Ipi.jsc.nasa.gov)

(Received May 28, 1996; revised September 5, 1996;

accepted September 12, 1996.) 